IFN Working Paper No. 922, 2012

\title{
Employee Compensation in Entrepreneurial Companies
}

Ola Bengtsson and John R. M. Hand 


\title{
Employee Compensation in Entrepreneurial Companies
}

\author{
Ola Bengtsson* and John R. M. Hand**
}

First draft: May 2010

This draft: July, 2012

\begin{abstract}
Despite the central role played by human capital in entrepreneurship, little is known about how employees in entrepreneurial firms are compensated and incentivized. We address this gap in the literature by studying 18,935 non-CEO compensation contracts across 1,809 privately-held venture-backed companies. Our key finding is that employee compensation varies with the degree to which VCs versus founders control the business. We show that relative to founder-controlled firms, VC-controlled firms pay their hired-on (i.e., non-founder) employees higher cash salaries, provide stronger cash and equity incentives, and have more formal pay policies in place. We also observe that founder employees earn less cash pay and face weaker cash incentives than do hired-on employees, but have stronger equity incentives. We propose that the compensation differences we identify arise because the preferences and capabilities of controlling shareholders significantly influence the quality of the human capital attracted and retained by the firm.
\end{abstract}

*Lund University School of Economics and Management and **University of North Carolina Chapel Hill. We are grateful to VentureOne and Brendan Hughes for providing their survey data, and for valuable comments from Xuan Tian, Andrew Ellul and workshop participants at Drexel University, the Fourth Annual Conference on Entrepreneurship and Innovation at Northwestern University, and the IFN Stockholm Conference. All errors are our own. Contact author: ola.bengtsson@nek.lu.se. Ola Bengtsson is grateful for financial support from the Marianne and Marcus Wallenberg Foundation. 


\section{Introduction}

Entrepreneurs play a vital role in fostering innovation and creating economic growth as they strive to commercialize their new ideas and inventions (Schumpeter, 1934; Baumol, Litan and Schramm, 2007). The highly personal nature of entrepreneurship therefore means that the point in time at which a founder cedes decision-making control to outside investors is often a watershed event for the company. Not only may outside investors move swiftly once control is in their hands to make major changes to the firm's strategy, operations and governance (Burton, 1999; Hellmann and Puri, 2002a, 2002b; Spulber, 2009), but the very nature of what it means to employees to work for the firm may be transformed.

In this study we expand empirically on this potential transformation by proposing that employee compensation in entrepreneurial firms depends on whether founders or outside investors control the firm. Our empirical analysis centers on privately-held companies that receive financing from venture capitalist (VC) investors. Venture-backed firms begin as a business plan and, if successful, grow rapidly to become professionalized businesses that are either taken public or acquired. Embedded in their prototypical life cycle is not only the shifting of corporate power away from the firm's founder, but a complex matching of supply of employee skills and preferences with the shifting demands of the firm's production function.

Despite the real-world importance of human capital in venture-backed firms, relatively little is known empirically about how such firms design their compensation contracts because of a lack of detailed, large scale compensation data on employee pay. We address the data problem by using a large sample of proprietary surveys collected by VentureOne, a leading data provider in the venture industry, during the period 2002-2007. Our sample covers 1,809 different venture-backed firms and contains longitudinal data on business performance, ownership structure, organizational design, and VC financing. For each firm in a given survey, and for up to 50 employees per firm, we have detailed data on employee salary, bonus, and equity holdings. In total, we study 18,935 compensation contracts spanning executives who hold the rank of chief ( $\mathrm{CFO}, \mathrm{COO}, \mathrm{CIO}, \mathrm{CSO}$, etc.), vice president or director (hereafter referred to 
in total as "employees"). ${ }^{1}$ Importantly, we exclude all CEOs from our sample, because we want to restrict our attention to employees and not the firm's primary decision-maker.

The large and unusually detailed sample of compensation contracts that we analyze allows us to take a detailed look "under the compensation hood" of private entrepreneurial firms. Although the firms we study are small at the time we study them (the typical firm is 4 years old, has 47 employees and $\$ 10$ million in revenues), our data frequently covers every employee working at the firm. As such, our 'wholeorganization' perspective contrasts with prior compensation research in economics and finance that has focused on large public companies, where the compensation disclosures required by the SEC limit research to the five most highly paid management team members-clearly but a very small fraction of all employees.

We undertake cross-sectional analyses on three dimensions of employee compensation contracts across firm-years in which firms are founder-dominated versus VC-dominated: [1] The use of formal compensation policies; [2] the level of employee cash pay; and [3] the strength of cash and equity incentives. We construct two proxies for founder-dominance, defined as the degree of influence founders have over critical decisions relative to VC investors. Our first proxy is an indicator set to one if one of the firm's founders is CEO at the time of the survey, which is the case in about $40 \%$ of firm-years, and zero otherwise. Our second proxy is an indicator set to one if VCs own a minority of the equity (they are "minority VCs"), which is the case in about $80 \%$ of firm-years, and zero otherwise. We do not have access to detailed data on VC contractual terms, so we rely on the argument that VCs in general have more influence over the firm's decision-making when they hold a majority ownership stake (Kaplan and Stromberg, 2003). ${ }^{2}$ As predicted by the idea that firms with founder CEOs are likely to have raised less VC financing and ceded less ownership to VCs, our proxies are significantly positively correlated.

\footnotetext{
${ }^{1}$ We do not study employees below the Director level because their work tasks are more standardized and thus less sensitive to the degree of founder/investor dominance. Unreported tests confirm this proposition. ${ }^{2}$ Kaplan and Stromberg (2003, p.308) find that "when VCs control the board, they typically also have a voting majority; when founders control the board, the founder group tends to control a voting majority."
} 
We begin our empirical investigation of employee compensation in venture-backed firms by building from prior work that has shown that VCs often professionalize their portfolio companies by formalizing firms' internal organizations (Burton, 1999; Hellmann and Puri, 2002a, 2002b). Specifically, we compare the number of formal compensation policies in place at founder-dominated versus VCdominated venture-backed firms. VentureOne's surveys include information about the presence or absence of compensation policies, such a formal compensation plan, a formal bonus plan, an option grant guide, the existence of sales commissions, and whether bonuses are awarded to new hires. We find that these policies are less likely to be in place for firms with a founder CEO, and less likely to be in place for firms with minority VCs. Our results hold after controlling for various firm characteristics including industry, size, operating performance and headquarter location.

We then investigate the association between founder-dominance and the level of employee cash pay, and find that employees in VC-dominated firms earn higher cash pay than do employees in founderdominated firms. Univariate comparisons indicate that the average cash (salary + bonus) pay is about $\$ 20,000$ (14\%) higher for employees who work in firms run by non-founder CEOs or minority VCs. This result robustly holds in subsamples formed on employee rank, firm characteristics and time period, and it survives a battery of firm-specific controls including the number of the firm's employees which prior studies has shown to be positively correlated with the level of employee cash compensation (Brown and Medoff, 1989; Groshen, 1991; Idson and Oi, 1999; Fox, 2009). We further use the number of formal compensation policies as an explanatory variable in analyzing employee pay, and show that employees receive higher cash pay in firms that have a greater number of formal pay policies.

We next uncover a notably asymmetric difference in cash pay between employees who help launched the startup (founder employees) and employees who join the firm later on (hired-on employees). ${ }^{3}$ Founder employees on average earn lower cash compensation than do hired-on employees (Hamilton, 2000; Wasserman, 2003; Hellmann and Wasserman, 2011; Bengtsson and Hand, 2011), and

\footnotetext{
${ }^{3}$ Many firms have multiple founders. Thus, we can therefore separately study how compensation contracts differ for (i) founder versus hired-on employees, and (ii) companies with a founder CEO versus a hired-on CEO.
} 
the relationship between founder-dominance and employee cash pay appears weaker for founder employees.

We also study the strength of employees' compensation-based incentives. Our first test investigates whether founder-dominance is related to performance-based incentives in the form of cash bonuses. We find that employees are more likely to receive a cash bonus if they work in a VC-dominated firm. Our second test examines whether founder-dominance is related to employees' equity incentives, since equity in the form of stock and/or options can generate substantial payoffs for employees if the firm is sold or goes public. We show that employees in VC-dominated firms have larger equity holdings, and that this relation appears weaker for founder employees.

In the last part of our paper, we investigate economic explanations for our findings and examine the potential channels through which the relative degree of $\mathrm{VC} /$ founder influence might affect the nature of employment in venture-backed firms and thus the design of employee compensation contracts.

The first channel we explore is the proposition that employee work tasks are relatively simple early on in the firm's lifecycle when the founder is in control, but become more challenging as VCs invest, professionalize and rapidly develop the firm. Under this explanation, employees working in VCdominated firms will demand higher compensation levels and need stronger cash and/or equity incentives because the changes wrought by VC mean that employees work on tasks that have a higher marginal productivity.

Data limitations preclude us from directly measuring the work tasks that employees perform. We therefore use observable firm characteristics such as firm age, number of employees, revenues and profitability as proxies for the marginal productivity of work tasks. We find that for these characteristics, VC-dominated firms do not appear to be unambiguously more mature or more developed than founderdominated firms. For example, while we show that VC-dominated firms have a greater number of employees it is also the case that they have lower revenues and are more likely to be unprofitable. This 
mixed nature of these results suggests that differences in the marginal productivity of employee work tasks are not the main explanation for the differences we observe in compensation contracts. ${ }^{4}$

The second channel through which the relative degree of $\mathrm{VC} /$ founder influence might shape employee compensation is if employees in VC-dominated firms intrinsically have more valuable human capital. We are unable to test this argument in our dataset because VentureOne's surveys do not include biographical information on employees, and the anonymous nature of employee data means that we are unable to find the biographical information for our sample firms elsewhere. We try to finesse this problem by creating an additional dataset using CapitalIQ, a large provider of a wide variety of data on both private and public firms. Using CapitalIQ, we collect all the written biographies available for non-CEO employees in U.S. privately-held venture-backed firms in October 2011. In total, we obtain 14,329 such biographies representing 7,837 unique firms. ${ }^{5}$ Although our CapitalIQ dataset does represent a broad cross-section of entrepreneurial firms, it is a wholly contemporaneous snapshot and as such contains no historical information. It is also the case that CapitalIQ does not contain information about employee compensation contracts, which prevents us from relating the design of compensation contracts to employees' personal and professional characteristics.

After coding the content of the employee biographies, we find strong evidence that VCdominated firms on average have more seasoned employees. Our tests reveal that employees in firms with a non-founder CEO are older, have more affiliations with other companies/organizations, and are more likely to hold a Ph.D. degree. These results broadly support the argument that VCs help entrepreneurial firms to better attract and retain intrinsically high-quality employees, who therefore demand more attractive compensation packages.

Our analysis indicates that differences in human capital are a plausible explanation for the variation in employee compensation contracts that is associated with the degree to which VCs versus

\footnotetext{
${ }^{4}$ Importantly, results on employee compensation contracts hold after we control for observable measures of the firm's maturity and operating performance, and the amount raised by VCs in previous rounds.

${ }^{5}$ The CapitalIQ dataset has broad coverage of locations (with California, Massachusetts, Texas and New York being the most represented states) and industries (with software, semiconductor, communications, healthcare, biotechnology, and pharmaceuticals being the most represented industries).
} 
founders control the firm. However, we acknowledge that we cannot establish that differences in human capital are the only explanation, because VentureOne's survey data cannot be merged with CapitalIQ's employee biographical data. As a result, we cannot test whether the association between employee compensation contracts and the degree of $\mathrm{VC}$ versus founder control remains significant after controlling for employee human capital. Indeed, a simplified benchmarking comparison based on our estimated results suggests that differences in employee human capital are unlikely to be the only determinant of variation in employee compensation contracts as a function of $\mathrm{VC} /$ founder control.

In summary, our paper presents four novel findings regarding non-CEO employee compensation in entrepreneurial firms. First, we show that VC-dominated firms have more formal compensation policies in place. Second, we find that employees in VC-dominated firms earn higher cash pay than do their counterparts in founder-dominated firms. Third, we observe that employees in VC-dominated firms face stronger cash and equity incentives than do employees in founder-dominated firms. Finally, we show that founder employees have markedly different compensation contracts than do hired-on employees. We conclude that these empirical facts are best explained by differences in the intrinsic quality of employee human capital across the two types of venture-backed companies, more than by changes in the nature of work tasks arising from VCs professionalizing and rapidly developing the firm when they gain control.

Our paper contributes to the growing literature that studies how VCs, by virtue of being active and sophisticated investors, shape the internal environments of entrepreneurial firms. Gorman and Sahlman (1989), Sapienza (1992), Sapienza, Manigart and Vermeir (1996) and Hsu (2004) report survey evidence that VCs are viewed as valuable beyond the financing they provide, and Puri and Zarutskie (2012) and Chemmanur, Krishnan and Nandy (2008) find in Census-based analyses that venture-backed firms grow more rapidly and have higher productivity than do non-venture-backed firms. Our study adds to this literature by bringing to light the role that the compensation of non-CEO employees plays in the VC professionalization of technology-intensive startups. The paper closest to ours is Hellmann and Puri (2002b) who also present empirical evidence on how VCs professionalize the internal organization of entrepreneurial firms. Our analysis complements and extends theirs in that we study a more recent sample 
that is ten times larger and includes firms from all over the U.S. We also examine employee compensation contracts in lieu of team building and CEO turnover; and we study differences within venture-backed firms rather than across venture-backed versus non-venture-backed firms.

Our study further adds to research that has shown that self-employed individuals (i.e., founders in a very real sense of the word) earn less than do salaried workers (Carrington, McCue and Pierce, 1996; Hamilton, 2000; Wasserman, 2003; Hurst and Pugsley, 2011). Our analysis is unique, however, in that we find differences in compensation contracts both across founders and non-founders, and across employees in VC-dominated and founder-dominated firms

Finally, our study complements papers in finance by Bertrand and Mullainathan (1999, 2003) and Cronqvist et al. (2008) that relate the structure of employee compensation in public firms to the balance of power between investors and managers. However, in sharp contrast to Bertrand and Mullainathan (1999, 2003) and Cronqvist et al. (2008) who show that workers are paid more when investors are less powerful, consistent with CEOs of mature firms having a taste for the "quiet life" that comes with less aggressive bargaining with workers, we find that the opposite relation holds in private VC-backed firms. Since the firms we study can only survive by growing and innovating, we argue that their compensation contracts cannot reflect or be due to "quiet life" concerns.

The remainder of our study is laid out as follows. In Section 2 we describe the sample of VentureOne Compensation surveys, present our proxies for founder-dominance, and discuss the limitations of our approach. Section 3 presents empirical results on formal compensation policies, employee cash compensation levels and on incentives. In Section 4, we discuss potential economic explanations for our findings and empirically assess them using data taken from CapitalIQ. We conclude the paper with a short summary of our results. 


\section{Data}

\subsection{Company-Year Sample}

Our dataset derives from detailed surveys conducted bi-annually between 2002 and 2007 by VentureOne, a primary worldwide provider of information about VC investments and funds. ${ }^{6}$ In each proprietary CompensationPro $^{\mathrm{TM}}$ survey, VentureOne emailed a multipage, web-based compensation questionnaire to the roughly 7,000 venture-backed U.S. firms in its financing database that at the time it classified as being private and independent. The questionnaire asked for a broad set of compensation and business-related data. For example, companies were asked to indicate the dollar values of the base salary, bonuses, and other cash compensation of every employee (up to a maximum of 50 people from the most senior person down); the total shares of founders' stock and exercised and unexercised options that each held; and the total fully diluted preferred and common shares the companies had outstanding. In terms of business information, VentureOne asked each company to provide information concerning its formal compensation policies, actual revenues for its most recent fiscal year, expected revenues for its current fiscal year, the number of employees that were in place at the end of its most recent fiscal year, and the number of employees it expected to have at the end of its current fiscal year.

Ten CompensationPro ${ }^{\mathrm{TM}}$ surveys spanning the period 2002-2007 make up our sample. For firms that responded to both spring and fall surveys in a given year we use only the spring survey to avoid oversampling. We integrate this compensation data with information from VentureOne's financing and general support databases. To be included in our final sample, a company needed to provide information about its U.S. state location, industry, prior year revenues and employees, and equity ownership for both individual employees and VCs as a group. Each firm also needed to have closed at least one seed or VC financing round prior to the survey date. A small number of firms were excluded because the company had raised more than seven financing rounds, or the financing amount of the last round was not disclosed, or the data were obviously incorrect, or the firm was founded before 1980 (before which VC data was

\footnotetext{
${ }^{6}$ The authors were generously granted access to VentureOne's data after signing strict nondisclosure agreements.
} 
much less reliable). As reported in Panels A and B of Table 1, our total sample consists of 3,105 company-years derived from 1,809 unique venture-backed firms.

\section{$2.2 \quad$ Employee-Year Sample}

The two main units of observation in our tests of employee pay are [1] a unique employee in a given survey, which we define as an employee-year, and [2] a unique company in a given survey, which we define as a company-year or firm-year. Since our goal is to study only non-CEO employee compensation we exclude all CEOs and Presidents from our analysis. ${ }^{7}$ We also omit any employee who did not at least hold the rank of Director because lower rank employees conduct more straightforward tasks for which compensation contracts are a priori likely to be standardized across companies and therefore not influenced by whether the firm is dominated more by founders or by VCs. As reported in Panel C of Table 1, the surveys collectively provide compensation data for 18,935 employee-years, about $23 \%$ of which are Chiefs (e.g., Chief Financial Officer, Chief Operating Officer or Chief Medical Officer), 44\% are Vice Presidents and 33\% are Directors.

Panel C also tabulates our sample by whether employees are founders or were hired-on later. About one in eight employees in our sample is a company founder, and founders are more likely than other employees to hold a senior rank. Because venture-backed companies are often founded by teams of individuals, we frequently have data on multiple founders per unique firm-year in our sample. ${ }^{8}$ This enables us to contrast employee compensation contracts along two dimensions: (a) whether the employee him/herself is a founder or is hired-on, and (b) whether the employee works in a firm that has a CEO who is a founder or who is hired-on. In our tests, we construct variables that capture each dimension, and a variable that captures their interaction.

\footnotetext{
${ }^{7}$ Bengtsson and Hand (2011) analyze CEO compensation in venture-backed firms using VentureOne data not dissimilar to that used in this paper. The findings are that CEOs receive higher cash compensation when the company achieves operating success and/or successfully attracts more VC financing. ${ }^{8}$ About two thirds of the companies in our sample report having more than one founder.
} 


\subsection{Proxies for Founder-Dominance}

Panel D of Table 1 reports summary statistics on the two proxies we use to measure the relative degree of founder/VC dominance in venture-backed companies. We define both proxies so they take the value 1 if the company is founder-dominated and 0 if it is not.

The first proxy, CEO Founder, captures whether one of the company's founders is the CEO at the time of the survey. About $40 \%$ of company-years have a founder CEO. The second proxy, VC Minority Ownership, captures whether the VC owns a minority of the firm's outstanding equity (preferred and common shares combined). ${ }^{9}$ About $77 \%$ of all company-years have a VC minority. While holding only a minority of the outstanding shares makes it difficult for VCs to impose their will through shareholder voting, VCs can still significantly influence the firm via their presence on the Board (Lerner, 1995; Baker and Gompers, 2003; Kaplan and Strömberg, 2003; Wongsunwai, 2012). They may also include protective provisions in their financing contracts with the firm such that the CEO has to seek VC approval before making important business decisions (Gompers, 1988; Bengtsson, 2011). While our data do not allow us to empirically measure the allocation of board seats, protective provisions and other contractual rights, Kaplan and Stromberg (2003) have shown that firms where VCs hold a majority of the shares they are more likely to exert more board-based control. Thus, our identification is based on the reasonable argument that VCs exert more decision-making control when they have a greater equity ownership stake.

Although our two proxies capture different conceptual aspects of founder-dominance, they are positively correlated. Appendix Table A presents a detailed analysis of their empirical association. For example, we find that companies with a founder CEO have lower VC equity ownership and raise smaller amounts of VC financing, partly because they raise fewer rounds of financing and partly because they raise smaller amounts per round. On the whole, Appendix Table A supports the proposition that there is a tension between founders and VCs with regard to their influence over the company. However, our results do not reveal the mechanism underlying this tension because they necessarily show only correlations, not

\footnotetext{
${ }^{9}$ In untabulated regressions we replaced VC Minority Ownership with a continuous measure of the VC's equity ownership and obtained qualitatively very similar results.
} 
causation. We note that one possibility is that a founder CEO is less willing to cede power to VCs and thereby lose his non-pecuniary work benefits. Alternatively, VCs with more influence over the firm's decision making may be more likely to replace the founder CEO with a more professional CEO.

\section{$2.4 \quad$ Selection Bias}

Our sample of 1,809 firms covers approximately $20 \%$ of all U.S. venture-backed companies during the period 2002-2007. ${ }^{10}$ As such, it is very much larger than the samples used by other studies of the inner workings of venture-backed companies. ${ }^{11}$ As reported in Panel E of Table 1, our sample is well represented in terms of company industries and geographical locations, with almost two thirds of all survey responses coming from the large VC clusters in California, Massachusetts and Texas. In untabulated analysis, we compare the industry and year composition of our sample with that of the VentureOne universe, and find that our sample is comparable along these dimensions. The typical company in our database has 47 employees, $\$ 10$ million in annual revenues, is 4.1 years old and has raised a total of $\$ 17.4$ million in VC funding. The large standard deviations associated with these company characteristics reflect the broad cross-section of venture-backed firms in our sample.

Any study based on a survey with less than a $100 \%$ response rate may be subject to sample selection biases. We note that anyselection biases related to observable dimensions reported in panel $\mathrm{E}$ of Table 1 are absorbed in our main regression specifications because we include in our regressions controls for company characteristics and a full set of industry, state and survey year dummies. We nevertheless acknowledge that the inferences we draw from our analyses might still reflect selection biases pertaining

\footnotetext{
${ }^{10}$ The coverage of our survey sample differs slightly from that of the full VentureOne dataset in that we undersample 2002 and 2003, and oversample 2006 and 2007. We used data from VentureXpert to assess the nature of the selection of our sample. With regard to, we oversample companies based in California and Massachusetts. With regard to industries, we oversample companies in biotechnology and software, but undersample companies in medical/life science. The average company age in our sample is slightly lower the VentureXpert average. We cannot assess sample bias with regards to employees, revenues, and profitability because these variables are not consistently reported in VentureXpert.

${ }^{11}$ The number of sample companies is 170 in Hellman and Puri (2002), 119 in Kaplan and Strömberg (2003), 51 in Hsu (2004), 132 in Cumming (2008), 50 in Kaplan, Strömberg and Sensoy (2009), and 50 in Broughman and Fried (2010).
} 
to unobserved dimensions. For example, VentureOne surveys may oversample successful companies because successful companies are more willing to report to VentureOne their superior performance and more generous compensation contracts. The potential presence of such oversampling means that the reported summary statistics on company performance and employee pay should be interpreted with caution. At the same time, such oversampling does not mean that the correlations we observe between compensation contracts and the founder-dominance are biased. That would only occur if the oversampling exactly follows the detailed empirical patterns we uncover in our analysis. However, it is difficult to see how or why a more VC-dominated company that pays higher cash compensation only for its hired-on employees would be more likely to respond to the VentureOne survey than a VC-dominated company with lower cash compensation to such employees, or how this response likelihood would then also be the reverse for founder-dominated companies. Furthermore, this oversampling has to apply to most important subsample of venture-backed companies, yet we are able to show later in our paper that our results are robust to different subsample specifications.

\subsection{Data Limitation}

Before detailing our test results, we caveat that we have no information on employees' personal characteristics, education or work history. As such, we are unable in our regressions of employee compensation and incentives to directly control for differences in human capital. We are, though, able to control for differences in human capital that follow from the part of employee-to-company matching that stems from company characteristics such as company industry, location, size, operating performance and VC fundraising success. We can also control for differences in human capital that manifest themselves in the employee's rank (Chief, Vice President or Director). Nevertheless, even in the presence of these controls it remains possible that some results may be due to differences in employee human capital. In Section 4 we explore the possibility that VC- and founder-dominated companies differ with respect to the quality of employee human capital. We find evidence of such difference along many relevant dimensions. 


\section{Empirical Results}

\subsection{Results on Compensation Policies}

Our first tests estimate whether the presence or absence of formal compensation policies is associated with founder-dominance in VC-backed firms. VentureOne's surveys ask respondents to report the presence of five policies: A formal compensation policy, a formal bonus policy, an option grant policy, a sales commission policy, and a hire-on bonus policy. Panel F of Table 1 reports that average number of policies our sample firms have in place is 2.6.

Table 2 reports the results of ordered logit regressions, with residuals clustered by company, where the dependent variable is the Number of Formal Compensation Policies. The sample is 3,105 company-years. Specification 1 is a univariate regression with our first proxy for founder-dominance, CEO Founder, as the explanatory variable. We observe that firms with a founder CEO at the time VentureOne's CompensationPro survey was taken have 0.24 fewer policies in place than do firms with a non-founder CEO. Specification 2 is a univariate regression with our second proxy for founderdominance, VC Minority Ownership, as the explanatory variable. Firms with a VC minority have 0.29 fewer policies than firms with a VC majority. Specification 3 includes both proxies in the regression as well as controls for company characteristics, industry dummies (based on VentureOne 16-segment classification), U.S. state location and the survey year. We note that the negative correlations between each of our proxies for founder-dominance and the number of formal compensation policies remain significant. Inspection of the estimated coefficients on the control variables in Specification 3 indicates that firms with more employees and larger revenues have a larger number of formal compensation policies.

In summary of Table 2's results, we robustly find that more VC-dominated companies have a larger number of formal compensation policies in place. ${ }^{12}$ This result complements Hellmann and Puri (2002b) who show that venture-backed firms introduce a stock option plan faster than do non-venture-

\footnotetext{
${ }^{12}$ Appendix Table $\mathrm{C}$ presents robustness where we run separate regressions for each of the five compensation policies.
} 
backed firms, and that VCs influence the introduction of a human resource policy more than do other financiers.

\subsection{Results on the Level of Employee Cash Compensation}

As reported in Panel G of Table 1, the average non-CEO employee salary in our sample is about $\$ 145,000$ and the average bonus is about $\$ 14,000$. Total cash compensation averages $\$ 161,000$ but exhibits considerable variation, ranging between $\$ 5,000$ and $\$ 2,350,000 .{ }^{13}$

Table 3 reports the results of OLS regressions where the sample consists of 18,935 employee compensation contracts. We use the log of the Employee's Total Cash Compensation as the dependent variable so we can make inferences about percentage changes. Residuals are clustered by company. In untabulated tests where we also cluster by year (following Petersen, 2009), we find similar results.

In Specification 1 we include only our first proxy for founder-dominance, CEO Founder, as an explanatory variable. In this univariate regression, employee compensation is about $5 \%$ lower if the company has a founder CEO. In Specification 2 we include only our second proxy for founderdominance, VC Minority Ownership, and find that employee cash pay is about 9\% lower for companies in which VCs hold a minority of the outstanding equity.

In specification 3 we include both CEO Founder and VC Minority Owners and control for company characteristics and fixed effects for company industry (based on VentureOne's 16-segment industry classification), U.S. state location and the survey year. Location fixed effects are important because they absorb variation in cash compensation due to differences in the cost of living. We also include dummies to capture the rank of the employee (Chief, Vice President or Director) and thereby the associated differences in the employee's work responsibilities and human capital. We find that the negative association between founder-dominance and employee cash compensation remains significant, though with smaller estimated coefficients, in this specification. The adjusted regression R-squared of

\footnotetext{
${ }^{13}$ In addition to salary and bonus, total cash compensation includes other smaller forms of compensation. This is why the sum of average salary and average bonus $(\$ 145,000+\$ 14,000=\$ 159,000)$ does not add up to the average total cash compensation of $\$ 161,000$
} 
0.37 suggests that our battery of controls and dummies captures well the key determinants of employee cash compensation.

We note that employee pay is higher for older companies, companies with higher revenues, companies that have raised more VC financing, and companies with more employees. Although similar results are found in Brown and Medoff, (1989), Groshen (1991), Idson and Oi (1999) and Fox (2009), our study is the first to show these positive correlations in a sample of only venture-backed firms.

Specification 3 also includes the dummy variable Employee is Founder. As in Wasserman (2003), we find that founder employees on average earn 5\% lower cash compensation. Importantly, however, the difference between founder-dominated and VC-dominated firms remains significant after controlling for whether the employee was a founder, indicating that they are two separate factors that each help explain employee cash compensation.

In Specification 4 we include the Number of Formal Compensation Policies as an explanatory variable. ${ }^{14}$ We observe that the number of such policies is positively correlated with higher employee cash compensation. Among other reasons, this may be because increases in cash compensation follow the introduction of formal compensation policies. Alternatively, it may be that firms that pay their employees higher cash pay are more prone to introducing formal compensation policies. ${ }^{15}$

In Appendix Table $\mathrm{C}$ we report the results of extensive robustness tests of the results documented in Section 3.2. We run regressions identical to Specification 3 of Table 3 for different subsamples formed on employee rank, company characteristics or survey year respectively. For brevity Table B reports only the estimated coefficients on CEO Founder, VC Minority Ownership and Employee is Founder. We find that our two main results - that employee cash compensation is lower for founder-dominated companies, and lower for employees who themselves are founders - hold robustly in these subsample regressions.

${ }^{14}$ In this specification, we exclude Employee is Founder. In an untabulated test, we include both Employee is Founder and Number of Formal Compensation Policies and confirm the results in specifications 3 and 4 .

${ }^{15}$ In an unreported test, we interact Number of Formal Compensation Policies with each of our proxies for founder dominance. We find that both coefficients are positive and the interaction with VC Minority Ownership significantly so. This finding suggests that founder-dominance is more important when the company has more compensation policies in place. 


\subsection{Results on Cash Bonus Incentives}

Our third set of tests investigates whether and how founder-dominance and the employee's founder/notfounder status are associated with employee incentives. We begin by examining cash incentives in the form of a cash bonus, and then test equity incentives via employees' holdings of common shares and stock options. Results are presented in Table 4.

In our sample, $38 \%$ of all employees receive a cash bonus (Panel G of Table 1). We therefore test to see how the likelihood of receiving a cash bonus is related to our two proxies for founder-dominance. Specifications 1 and 2 present the results of probit regressions where the dependent variable takes the value 1 if the employee received a cash bonus and 0 otherwise. Specification 1 includes both of the proxies CEO Founder and VC Minority Ownership. We observe that employees in companies with a founder CEO are $4 \%$ less likely to receive a bonus, but we find no significant association between $V C$ Minority Ownership and the likelihood of a bonus. ${ }^{16}$ However, when in Specification 2 we include both proxies and control for company characteristics, industry dummies (based on VentureOne's 16-segment classification), U.S. state location and survey year, we find that each proxy for founder-dominance is negatively related to the likelihood of employees receiving a bonus. Examining the coefficients on the control variables we also observe that firms with higher revenues and profitable firms are more likely to have employee cash bonuses. Specification 2 also includes Employee is Founder as an explanatory variable. We find that founder employees are significantly less likely to receive a bonus as compared to hired-on employees.

\subsection{Results on Equity Ownership}

We turn next to study employees' equity incentives. In doing so, we note that VentureOne's CompensationPro surveys do not ask firms to provide data on each employee's yearly grant(s) of options

\footnotetext{
${ }^{16}$ We find similar results in untabulated regressions where we include each proxy separately.
} 
and stock, but instead they ask for information about each employee's total ownership of the firm's fully diluted equity (preferred plus common plus granted options) at the survey date.

As a result, the dependent variable in specifications 3 and 4 of Table 4 is the Employee's Percentage Equity Ownership and the estimation method is tobit. We observe that when per specification 3 we include our two proxies for founder-dominance we find no significant association for CEO Founder but observe a significantly positive estimated coefficient on VC Minority Ownership. These patterns change after we include our battery of control variables, in that in multivariate specification 4 we find that employees hold reliably lower equity ownership stakes if the company has a founder CEO, but the same ownership stake no matter whether VCs have a minority or a majority ownership. We interpret these results as being mildly supportive of the proposition that founder-dominated firms provide their employees weaker equity incentives than do VC-dominated firms. The estimated coefficients on the control variables indicate that employees receive smaller ownership stakes in larger companies (as measured by the total number of employees), companies which have raised larger amounts of VC financing, and firms with smaller revenues.

In specification 4 we find that founder employees hold larger equity ownership stakes than those who are hired later on by virtue of the significantly positive coefficient estimate on the dummy variable Employee is Founder. In an untabulated analysis, we create proxies for the employee's total compensation (i.e., the sum of equity and cash pay) and find that founder employees overall receive higher compensation than hired-on employees. Put differently, the more valuable market value of equity stakes dominates the lower levels of cash pay.

\subsection{Results using Firm Fixed Effects}

We investigate the degree to which our findings remain robust in regressions that control for firm fixed effects. This estimation technique has the advantage of removing differences in compensation contracts that arise from across-firm variation in unobserved firm or employee characteristics. However, it has the disadvantage that it is characterized by weak statistical power, especially for our situation that 
investigates how founder-dominance relates to employee compensation. This is because of firms in our dataset, $56 \%$ respond to only one CompensationPro survey, and among the remaining $44 \%$ of firms there is little time-series variation in either of our proxies for founder-dominance. Specifically, only $22 \%$ of firms responding to more than one survey report a transition from a founder CEO to a hired-on CEO, and only $25 \%$ reported any transition from a VC minority to a VC majority ownership. In total, just $18 \%$ of all sample firms have a transition in either proxy. Such low within-firm variation implies that our fixed effect regressions are likely to manifest weak statistical power.

With this caveat in mind, Table 5 reports the results of firm fixed effect OLS regressions. In specification 1, the dependent variable is the Number of Formal Compensation Policies and the sample is 3,105 company-years. We control for company characteristics, industry dummies (based on VentureOne 16-segment industry classification), U.S. state location and the survey year. Consistent with our previously discussed results, we observe negative estimated coefficients on CEO Founder and VC Minority Ownership, although not statistically significant.

Specifications 2 - 4 use different measures of the compensation contract as the dependent variable and control for company industry, location, survey year, and the employee's rank (Chief, Vice President or Director). In specification 2, the dependent variable is $\log$ of the Employee's Total Cash Compensation. We find negative, but statistically insignificant, estimated coefficients on CEO Founder and VC Minority Ownership. We find a significantly negative estimated coefficient on Employee is Founder and a significantly positive estimated coefficient on Number of Formal Compensation Policies. These results are qualitatively similar to our findings from the baseline regressions without firm fixed effects.

In specification 3, the dependent variable is Employee Receives Cash Bonus. We confirm the significantly negative estimated coefficient on VC Minority Ownership and significantly negative estimated coefficient on Employee is Founder. In specification 4, the dependent variable is Employee's Percentage Equity Ownership. We find no results for our two proxies of founder-dominance, but we 
confirm the significantly positive estimated coefficient on Employee is Founder from our earlier baseline tests estimated without firm fixed effects.

In summary, our tests based on estimating firm fixed effects models yield qualitatively similar results as our baseline tests, but as expected they also have less statistical significance, particularly for the proxies of founder dominance.

\subsection{Results on Interaction Effects}

Our tests thus far have shown that compensation contracts differ markedly between founders and hired-on employees. We next explore whether this difference is affected by the degree of founder/VC dominance by creating two new interaction variables: CEO Founder X Employee is Founder and VC Minority X Employee is Founder. Results when the interaction variables are included are presented in Table 6. Each of specifications $1-3$ in Table 6 has a different dependent variable, but uses the full employee-year sample with controls for company industry, location, survey year and the employee's rank (Chief, Vice President or Director). Residuals are clustered on company.

In specification 1, the dependent variable is log of the Employee's Total Cash Compensation and the estimation method is OLS. We find positive estimated coefficients on the interaction variables. However, only the coefficient on CEO Founder X Employee is Founder is statistically significant. In specification 2, the dependent variable is Employee Receives Cash Bonus and the estimation method is probit. We find statistically insignificant estimated coefficients on the interaction variables. Finally, in specification 3, the dependent variable is Employee's Percentage Equity Ownership. The estimated coefficient on the VC Minority X Employee is Founder is positive and statistically significant at the $1 \%$ level.

The patterns that emerge using the interaction variables suggest that the difference between compensation contracts across founders and hired-on employees is less pronounced for founderdominated companies (for cash pay and equity incentives). Indeed, we find that some estimated interaction coefficients have an estimated magnitude such that (a) any difference in the compensation of 
founders employees across founder- and VC-dominated companies is either quite small or non-existent, and (b) the difference in compensation contracts for hired-on employees across founder- and VCdominated companies is large and statistically significant both for cash compensation and for cash and equity incentives.

We find that after we include the interaction variables, the coefficient on Employee is Founder remain negative and significant. This indicates that founder employees consistently earn significantly different cash compensation.

\section{Potential Economic Explanations for Our Findings, and Additional Evidence}

Taken as a whole, our empirical analyses reveal several novel facts as to how employee compensation in entrepreneurial private firms varies with the relative degree of founder/VC dominance. We find that founder-dominated firms have fewer firm-wide compensation policies, lower levels of employee cash compensation, and weaker employee cash bonus and equity incentives. These differences are particularly pronounced for hired-on employees as compared to founder employees. We now turn to discuss two alternative economic explanations for our findings. The first is that employees have similar human capital but perform different work tasks across founder-dominated and VC-dominated firms. The second is that the quality of employee human capital differs across founder-dominated and VC-dominated firms.

\subsection{Employee Work Tasks}

A typical venture-backed firm begins its life as founder-dominated, and then may become VC-dominated after VCs invest and/or obtain control rights. Because the transition only takes place when both VCs choose to provide more capital and the firm chooses to accept the capital, there is a selection-based, endogenous relationship between the firm's relative $\mathrm{VC} /$ founder dominance and its characteristics - and that relationship may plausibly determine the nature of employees' work tasks. Greater involvement of VCs may also influence the firm's characteristics since VCs have different goals and abilities than do founders (Hellmann and Puri, 2002b; Spulber, 2009). 
However, it is not obvious what the relationship between the relative founder/VC dominance and firm characteristics will exactly be under the work tasks explanation. If VC-dominated firms are more mature and better performing than are founder-dominated firms, then per our empirical results presented in section 3, VC-dominated firms will offer their hired-on employees work tasks with marginal productivity and commensurately higher cash compensation, and stronger cash and equity incentives. Moreover, if the work tasks of founder employees remain similar (i.e., their marginal productivity is unchanged) after VCs take control, then this explanation may also illuminate our finding that founders' compensation is less sensitive to the firm's relative degree of founder/VC dominance. ${ }^{17}$

The challenge to this explanation is that our results on VC/founder dominance hold after we control for firm characteristics - the number of employees, revenues, profitability, age, development stage, number of VC rounds, and the aggregate financing amount - that likely also absorb important differences in the marginal productivity of employees' work tasks. With such controls in place, the explanation can only be valid if $\mathrm{VC}$-dominated firms are more mature and better performing along some dimension that we do not control for.

While we cannot rule out such an omitted-variable situation, we are able to shed some light on it by studying how our proxies for VC/founder dominance correlate with observable firm characteristics. We examine this in Table 7 where odd-numbered specifications include only our two proxies as independent variables, and even-numbered specifications add location, industry, year and round dummies. We study four observable firm characteristics, all of which likely correlate positively with the marginal productivity of employees' work tasks: Firm age, number of employees, annual revenues and profitability.

In specification 1 (which has no controls) we find that founder-dominated firms are younger than VC-dominated firms. However, in specification 2 where we include controls, the relationship becomes ambiguous in that we find that firms with a VC Minority Ownership are significantly younger, but firms

\footnotetext{
${ }^{17}$ An alternative mechanism is that founder employees receive non-pecuniary benefits from working in the firm they started, which weakens their bargaining power in compensation contract negotiations.
} 
where the $C E O$ is Founder are significantly older. Specification 3, which has no controls, shows that founder-dominated firms have more employees, but specification 4 shows that this association disappears after including controls. In specifications 5 and 6 , we show that founder-dominated firms have greater revenues. Similarly, specifications 7 and 8 show that founder-dominated firms are more likely to be profitable.

Our findings on revenues and profitability may seem surprising at first glance in that they indicate that VC-dominance is associated with worse, not better, operating performance. However, the negative coefficient on the focal variables may reasonably arise because internal and external financing sources are real-world substitutes. Put differently, companies that have access to more operational cash flows (i.e., revenues and profits) may be less likely to raise funds from outside investors.

Our analysis shows that founder-dominated firms are not obviously less mature or developed than VC-dominated firms based on observable firm characteristics. This makes it less likely that differences in the marginal productivity of employee work tasks implied by the firm's maturity and development stage are the main explanation for the differences we observe for employee compensation contracts. As we describe in the next subsection, we propose that differences in the quality of employee human capital is a candidate explanation in that regard.

\subsection{Employee Human Capital}

Beyond providing money, VCs assist their portfolio companies with strategic decision-making and operational support. Hsu (2004) shows that entrepreneurs value such help, and Sorensen (2007) finds that it can explain part of the variation in outcome success across experienced and non-experienced VCs. Hellmann and Puri (2002b) find that one way VCs provide operational support is to help the entrepreneurial firm attract high-level executives. Anecdotal evidence (and our own interviews with practitioners) confirms this idea. Most VCs work hard on building and maintaining relationships with talented executives who they believe could be suitable employees for their portfolio companies either right away or at some point in the future. 
From a conceptual standpoint, VCs may have two advantages over a founder when it comes to finding and attracting talented human capital. First, because VCs are involved in multiple entrepreneurial firms, they have more opportunities and stronger incentives to build networks of relationships with talented executives in a particular geographic and/or industry sector. This is particularly true for VCs who are members of syndication groups with other VCs. Learning-by-doing may also make VCs better at selecting talented executives and matching their human capital with portfolio firms' needs. Second, VC involvement in a firm may signal to prospective employees that the firm has a higher likelihood of becoming successful, thereby making employment in VC-backed companies more reliable and associated with a higher expected payoff from equity-based compensation.

VentureOne's CompensationPro database does not allow us to test the hypothesis that VCdominance is associated with more valuable employee human capital. Although VentureOne's surveys include details about the employee's compensation contract, they do not report any information about the employees' personal and professional backgrounds. Moreover, we cannot use other data sources to collect such information because the surveys are wholly anonymous (to us) with respect to the identity of the firms and the employees. We therefore seek to study the relations between VC/founder dominance and employee human capital through a different dataset.

To the best of our knowledge, there exists no publicly-available database that contains detailed and complete background information on a large sample of employees in U.S. venture-backed private firms. However, a substantial amount of such information is reported by CapitalIQ, a large data provider that covers both public and private firms. CapitalIQ collects its data on private firms by means of extensive searches of web-pages, press releases and news articles. We use the part of CapitalIQ's data that lists an employee's name, age, work affiliations, educational degree, and university attendance. ${ }^{18}$ Because

\footnotetext{
${ }^{18}$ We obtain data on employees' work affiliations in the following way. Based on information from the employee's biography, CapitalIQ lists the names of all firms (and in rare cases, non-firm organizations) that the employee has worked for or has served as a Director for. We exclude the focal firm from the list and count the raw number of an employee's affiliations. We do not differentiate between types of work affiliations because this data collection would be extremely time-consuming (it would have to be done entirely by hand).
} 
CapitalIQ reports this information on a continuously updated basis, no historical time-series information is available to us. This means that we analyze only a single snapshot of data, in our case downloaded in October 2011. In our data snapshot, we restrict our attention to firms that are (a) located in the U.S., (b) privately-held, (c) venture-backed firms, and (d) younger than ten years old. These restrictions ensure that our CapitalIQ dataset includes similar firms as our VentureOne survey dataset.

Because they are self-reported, the data from CapitalIQ may be subject to various sample selection biases. One such bias may be that firms typically report biographical information only on their top-level executives. We therefore restrict our focus to employees other than the CEO who hold a "Chief" position (e.g., $\mathrm{CFO}, \mathrm{COO}, \mathrm{CIO}$ ). Another bias may be that firms choose to report biographical information on only seasoned executives with stronger professional backgrounds, and do not report information about less seasoned executives. While we cannot assess the extent of this potential bias, we note that it will not affect the interpretation of our results unless the selective reporting is more prominent for VC-dominated firms. A final bias we consider is that it may be that very successful firms are more willing to report information than are less successful firms. Because CapitalIQ does not report information about the firm size or operating performance, we cannot assess the extent of this potential bias. Nonetheless, as we discussed in Section 2, this kind of self-reporting bias is similar to the potential oversampling of successful firms in VentureOne's data.

The final sample in our CapitalIQ dataset consists of 14,329 employees. For each employee, we create six proxies for the quality of his/her human capital: $\log (1+$ Age of Executive), Employee Has Any Affiliation, log (1+Number of Employee's Affiliations, Employee Holds a PhD degree, Employee Holds a PhD degree, and Employee Attended Top University. We interpret a higher value on each proxy as indicating that the executive has more valuable human capital. Table 8 reports regression results where the six proxies for the quality of employees' human capital are used as the dependent variable. The focal independent variable is one of our two proxies for founder-dominance, CEO Founder, which we also 
collect from CapitalIQ’s biographical data. ${ }^{19}$ Since CapitalIQ does not include information about equity ownership in private firms, we cannot create the VC Minority proxy for founder-dominance. The regressions include Employee is Founder and controls for employees and company age. ${ }^{20} \mathrm{We}$ include dummies that capture company U.S. state location, industry (using CapitalIQ's 140 industry segments), and the employee's job title. Residuals are clustered on company.

Our results reported in Table 8 are that specification 1 reveals that employees working for firms with a founder CEO are younger; specifications 2 and 3 show that they also have fewer work affiliations; and specification 4 indicates that they are less likely to hold a $\mathrm{PhD}$ degree. Specifications 5 and 6 find that employees working for firms with a founder CEO are no different with regard to their having an MBA or having attended a top university (defined as one of the 25 highest-ranked US universities). Overall, employees in founder-dominated firms are less seasoned and have less valuable human capital as compared to employees in VC-dominated firms. Under the plausible assumption that seasoned employees have higher wage expectations and greater bargaining power, we infer that the results from our CapitalIQ dataset are consistent with the proposition that greater VC control helps a firm attract more talented employees who earn higher cash compensation and require stronger cash and equity incentives.

We acknowledge, however, that we are unable to establish that differences in employee human capital are the only explanation for variation in employee compensation contracts based on VC versus founder control. To do so would require merging CapitalIQ's employee biographical data with VentureOne's survey data. This unfortunately is not possible because VentureOne deliberately removes the identity of a firm from its survey data. We thus recognize that there may be additional explanations for the differences we observe in employee compensation contracts between founder-dominated and VCdominated firms.

\footnotetext{
${ }^{19}$ Specifically, we study the biography of the CEO for each sample firm. If the CEO is also a founder of the firm, then CEO Founder is 1 , and is 0 otherwise.

${ }^{20}$ Data on employees and company age are often not reported. For each such variable, we capture missing observations with a dummy that is 1 if data is missing and 0 otherwise.
} 
In this regard, simplified calculations indeed point differences in human capital as not being the only explanation. An unreported univariate comparison of the CapitalIQ sample shows that the fraction of employees with a $\mathrm{PhD}$ degree is approximately $6 \%$ of employees for firms with a CEO founder (i.e., founder-dominated firms) versus $8 \%$ for other firms (i.e., VC-dominated firms). In a similar comparison, the fraction of employees with a prior affiliation, as reported by CapitalIQ, is about $40 \%$ of employees for firms with a CEO founder versus $46 \%$ for other firms. As discussed above, we cannot relate these differences to differences in cash pay. We therefore rely on Wasserman (2006) who reports that venturebacked firms provide employees with a $\mathrm{PhD}$ degree approximately $\$ 14,000$ more in cash pay, and that each year of (work) experience yields an additional $\$ 1,700$ in cash pay. ${ }^{21}$ Combining the relevant numbers just described yields the inference that the difference in the fraction of employees with $\mathrm{PhD}$ degree explains approximately $3.3 \%$ of the lower cash pay for firms with a founder CEO. ${ }^{22}$ Similarly, the difference in employee work experience explains approximately $12 \%$ of the lower cash pay for firms with a founder CEO. ${ }^{23}$ From these calculations we conclude that differences in employee human capital are part of, but unlikely to be the full explanation for to why employees in founder-dominated firms receive different compensation contracts.

The analyses reported in Table 8 also reveal that founder employees have significantly fewer affiliations than hired-on employees. This may in part explain our finding that founders receive lower cash pay. However, running counter to this possibility, we find that founder employees are more likely to

\footnotetext{
${ }^{21}$ Reported coefficients are from Model 1 of Table 3 of Wasserman (2006, p. 969). It is important here to note that Wasserman's sample covers the period 2000-2002 whereas our sample covers the period 20022007. The associations between employee compensation and human capital may be markedly different for these time periods.

${ }^{22}$ The estimate of $3.3 \%$ is calculated by multiplying $2 \%$ (the difference between the fraction of employees with a $\mathrm{PhD}$ degree for firms with a CEO founder and the fraction of employees with a $\mathrm{PhD}$ degree for firms that are VC-dominated) by $\$ 14,000$ (difference in cash pay for having a $\mathrm{PhD}$ degree, as reported by Wasserman 2006), dividing this product by $\$ 161,000$ (the average cash pay in the VentureOne sample) and then dividing the result by $5.3 \%$ (the coefficient on CEO Founder in the regression on cash pay, specification 1 of Table 3 ).

${ }^{23}$ The estimate of $12 \%$ is calculated by multiplying $6 \%$ (the difference in having a prior work affiliation versus not) by 10 (the assumed number of years greater work experience for employees with prior work affiliation), multiplying this by $\$ 1,700$ (the difference in cash pay per year of work experience, as reported by Wasserman 2006), dividing this result by $\$ 161,000$ and then dividing by $5.3 \%$.
} 
have attended a top university. We also find that older companies employ individuals who are older (a finding also observed by Oiumet and Zarutskie, 2011) but have fewer affiliations. Further, companies with more employees tend to have executives who have more affiliations. The latter finding is consistent with a span-of-control argument, according to which individuals with better human capital manage larger firms.

\section{Conclusions}

In this paper we have investigated how the nature of employee compensation contracts varies with the degree of VC versus founder influence in entrepreneurial venture-backed companies. Given that VCs can and do shape corporate policies, professionalize corporate operations, and hire and retain talented employees, we argue that it is plausible to expect employee compensation contracts to be different in firms where VCs have more influence and founders have less influence relative to firms where VCs have less influence and founders have more influence.

Using a large and novel compensation dataset in the form of VentureOne's proprietary CompensationPro surveys, we confirm this expectation and also document several new findings regarding employee compensation contracts in entrepreneurial companies. By analyzing the determinants of employee pay in 1,809 U.S. venture-backed firms between 2002 and 2007, we showed that hired-on employees in VC-dominated companies earn higher cash compensation and face stronger cash and equity-based incentives. The differences we observe are economically meaningful and survive a battery of controls regarding company characteristics. We also showed that founder employees not only receive lower cash compensation than hired-on employees but have compensation contracts that are less sensitive to the relative degree of founder/VC dominance.

One of two candidate economic explanations that we explore for our findings is that VCdominance is associated with employee work tasks that have higher marginal productivity, because the firm is more mature and developed by virtue of having been transitioned from founder-dominated into

being VC-dominated. As evidence against this explanation, however, we showed that VC-dominated 
firms are not unambiguously more mature or more developed. The competing explanation, for which we find more consistent support, is that greater VC involvement helps firms attract (and possibly also retain) employees with more valuable human capital. To test this explanation, we used data from CapitalIQ to show that employees in VC-dominated firms are older, have more other affiliations, and are more likely to hold a Ph.D.

The findings we presented have implications for our understanding of how entrepreneurial startups develop into mature firms and the role VCs play in this shaping this process. Although it is welldocumented that VCs provide value-adding support to their portfolio companies (Hsu, 2004; Sorensen, 2007), evidence on the precise nature of this support is only just beginning to emerge. We provide some of the first such evidence by showing that VCs affect how both founder-employees and hired-on are differentially paid and incentivized. We also report evidence that indicates that VCs help firms to hire seasoned executives, a finding that corroborates Hellmann and Puri (2002b) but adds new detail on the executives' biographies.

An important implication of our paper is that VCs' provision of operational support (for example, in the form of the hiring of new personnel) depends on the firm's relative dominance of VCs and the founders. That is, VCs provide more support when they have more control. By documenting this pattern, we uncover a relationship between how entrepreneurial firms develop and how contractual control rights in such firms are allocated (Kaplan and Stromberg, 2003; Cumming, 2008; Bengtsson, 2011). 


\section{References}

Baker, M. and P. Gompers, 2003, "The Determinants of Board Structure at the Initial Public Offering." Journal of Law \& Economics, 46, 2, 569-98.

Baumol, W. J., R. E. Litan, and C. J. Schramm, 2007, Good Capitalism, Bad Capitalism, and the Ecnomics of Growth and Properity. New Haven: Yale University Press.

Bengtsson, O., 2011, "Restrictive Covenants in Venture Capital Contracts.” Management Science, 57, 11, 1926-1943.

Bengtsson, O. and J. Hand, 2011, “CEO Compensation in Venture Capital Markets.” Journal of Business Venturing, 26, 391-411.

Bertrand, M. and S. Mullainathan, 1999, "Is There a Discretion in Wage Setting? A Test Using Takeover Legislation." RAND Journal of Economics, 30, 3, 535-554.

Bertrand, M. and S. Mullainathan, 2003, "Are Emily and Greg More Employable than Lakisha and Jamal? A Field Experiment on Labor Market Discrimination." American Economic Review, 94, 4, 991-1013.

Brown, C. and J. Medoff, 1989, "The Employer Size-Wage Effect." Journal of Political Economy, 97, 5, 1027-59.

Broughman, B. and J. Fried, 2010, "Renegotiation of Cash Flow Rights in the Sale of VC-Backed Firms." Journal of Financial Economics, 95, 3, 384-399.

Burton, B., 1999, "The Insider Share Dealing Controversy - Much Ado About Nothing?" The Bath Perspective, Spring, 12.

Carrington, W., K. McCue and B. Pierce, 1996, “The Role of Employer/Employee Interactions in Labor Market Cycles: Evidence from the Self-Employed.” Journal of Labor Economics, 14, 4, 571-602. 
Chemmanur, T., K. Krishnan and D. Nandy, 2008, "How Does Venture Capital Financing Improve Efficiency in Private Firms? A Look Beneath the Surface." Center for Economic Studies, U.S. Census Bureau, working papers \#08-16.

Cronqvist, H., F. Heyman, M. Nilsson, H. Svaleryd and J. Vlachos, 2009, "Do Entrenched Managers Pay Their Workers More?” Journal of Finance, 64, 309-339.

Cumming, D., 2008, "Contracts and Exits in Venture Capital Finance." Review of Financial Studies, 21, 5, 1947-1982.

Fox, J., 2009, "Firm-Size Wage Gaps, Job Responsibility, and Hierarchical Matching." Journal of Labor Economics, 27, 1, 83-126.

Gompers, P., 1998, "Venture Capital Growing Pains: Should the Market Diet?" Journal of Banking and Finance, 22, 6-8, 1089-1104.

Gompers, P. and J. Lerner, 2001, "The Venture Capital Revolution." Journal of Economic Perspectives, $15,2,145-168$.

Gorman, M. and W. Sahlman, 1989, "What Do Venture Capitalists Do?” Journal of Business Venturing, 4, 231-248.

Groshen, E., 1991, "Rising Inequality in a Salary Survey: Another Piece of the Puzzle." Federal Reserve Bank of Cleveland, working paper \#9121.

Hamilton, B., 2000, "Does Entrepreneurship Pay? An Empirical Analysis of the Returns to SelfEmployment." Journal of Political Economy, 108, 3, 604-631.

Hellmann, T. and M. Puri, 2002a, "On the Fundamental Role of Venture Capital." Economic Review, Atlanta Federal Reserve Bank, 87, 4. 
Hellmann, T. and M. Puri, 2002b, "Venture Capital and the Professionalization of Start-up Firms: Empirical Evidence," Journal of Finance, 57, 1, 169-197.

Hellmann, T. and N. Wasserman, 2011, "The First Deal: The Division of Founder Equity in New Ventures.” University of British Columbia and Harvard Business School, working paper.

Holmström, B., 1979, "Moral Hazard and Observability." Bell Journal of Economics, 10, 1, 74-91.

Holmström, B. and P. Milgrom, 1991, "Multitask Principal-Agent Analyses: Incentive Contracts, Asset Ownership, and Job Design." Journal of Law, Economics and Organization, 7, 24-52.

Hsu, D., 2004, "What Do Entrepreneurs Pay for Affiliation?" Journal of Finance, 59, 1805-1844.

Hurst, E. and B. Pugsley, 2011, "What do Small Businesses Do?" Brookings Papers on Economic Activity, Fall, 73-142.

Idson, T. and W. Oi, 1999, "Workers Are More Productive in Large Firms." American Economic Review, $89,2,104-108$.

Kaplan, S. and P. Strömberg, 2003, "Financial Contracting Theory Meets the Real World: Evidence from Venture Capital Contracts.” Review of Economic Studies, 70, 281-316.

Kaplan, S. N. and P. Strömberg, 2005, "Characteristics, Contracts and Actions: Evidence from Venture Capitalist Analyses." Journal of Finance, 59, 5, 2177-2210.

Kaplan S., B. Sensoy and P. Strömberg, 2009, "Should Investors Bet on the Jockey or the Horse? Evidence from the Evolution of Firms from Early Business Plans to Public Companies." Journal of Finance, 64, 1, 75-115.

Lerner, J., 1995, "Venture Capitalists and the Oversight of Private Firms." Journal of Finance, 50, 1, 30118. 
, H. Sapienza and W. Vermeir, 1996, "Venture Capitalist Governance and Value-Added in Four Countries," Journal of Business Venturing, 11, 6, 439 -469.

Ouimet, P. and R. Zarutskie, 2011, "Who Works for Startups? The Relation between Firm Age, Employee Age, and Growth.” Working paper, UNC Chapel Hill.

Petersen, M., 2009, Estimating Standard Errors in Finance Panel Data Sets: Comparing Approaches.” Review of Financial Studies, 22, 1, 435-480.

Puri, M. and R. Zarutskie, 2012, "On the Lifecycle Dynamics of Venture-Capital- and Non-VentureCapital-Financed Firms." Journal of Finance, forthcoming.

Sapienza, H., 1992, “When Do Venture Capitalists Add Value?” Journal of Business Venturing, 7, 9-27.

Schumpeter, J. A, 1997 [1934], The Theory of Economic Development. New Brunswick, NJ: Transaction Publishers.

Spulber, D., 2009, Microeconomics With Endogenous Entrepreneurs, Firms, Markets, and Organizations. Cambridge University Press.

Wasserman, N., 2003, "Founder-CEO Succession and the Paradox of Entrepreneurial Success." Organization Science, 14, 2, 149-172.

Wasserman, N., 2006, "Stewards, Agents, and the Founder Discount: Executive Compensation in New Ventures." Academy of Management Journal, 49, 5, 960-976.

Wongsunwai, W., 2012, "The Effect of External Monitoring on Accruals-Based and Real Earnings Management: Evidence from Venture-Backed Initial Public Offerings." Contemporary Accounting Review, forthcoming. 


\section{Table 1 - Sample Overview and Summary Statistics}

Sample comes from surveys of venture-backed U.S. companies conducted by VentureOne from 2002-2007. Each survey asks the company to provide data on firm performance and employee compensation. We limit our analysis to non-CEOs and employees with the rank of Director or above, and keep only one survey per firm per year. We match our sample with information on company characteristics, VC ownership, and financing from VentureOne's general databases. Observations with missing or obviously incorrect data are excluded. The final baseline sample consists of 3,105 company-years from 1,809 different firms and represents 18,935 employee-yearobservations. Panel A tabulates the sample by survey, Panel B by the number of surveys per company, and Panel $C$ by employee rank and employee founder status. Summary statistics are presented in Panel D for company characteristics, Panel E for our two proxies of relative founder$V C$ dominance, Panel $F$ for formal compensation policies, and Panel G for employee cash compensation and equity holdings.

Panel A: Tabulation by Survey (company-year observations)

\begin{tabular}{lcrr} 
Year & Total & \multicolumn{1}{c}{ Spring } & \multicolumn{1}{c}{ Fall } \\
2002 & $438(14 \%)$ & $438(14 \%)$ & $0(0 \%)$ \\
2003 & $365(12 \%)$ & $365(12 \%)$ & $0(0 \%)$ \\
2004 & $769(25 \%)$ & $573(18 \%)$ & $196(6 \%)$ \\
2005 & $555(18 \%)$ & $371(12 \%)$ & $184(6 \%)$ \\
2006 & $586(19 \%)$ & $490(16 \%)$ & $96(3 \%)$ \\
2007 & $392(13 \%)$ & $392(13 \%)$ & $0(0 \%)$ \\
Total & $3,105(100 \%)$ & $2,629(85 \%)$ & $476(15 \%)$
\end{tabular}

Panel B: Tabulation by Number of Company-Years per Company

\begin{tabular}{ccc} 
Surveys per Company & Company-Years & Companies \\
\cline { 2 - 3 } 1 & $1,010(33 \%)$ & $1,010(56 \%)$ \\
2 & $902(29 \%)$ & $451(25 \%)$ \\
3 & $702(23 \%)$ & $234(13 \%)$ \\
4 & $332(11 \%)$ & $83(5 \%)$ \\
5 & $135(4 \%)$ & $27(1 \%)$ \\
6 & $24(1 \%)$ & $4(0 \%)$ \\
Total & $3,105(100 \%)$ & $1,809(100 \%)$
\end{tabular}

Panel C: Tabulation by Employee Rank, and Founder vs. Hired-On Status (employee-year observations)

Employee Rank

Chief (CFO, COO, CIO, etc)

\begin{tabular}{ccc} 
All & Hired-On & Founder \\
\hline $4,349(23 \%)$ & $3,019(16 \%)$ & $1,330(7 \%)$ \\
$8,291(44 \%)$ & $7,466(39 \%)$ & $825(4 \%)$ \\
$6,295(33 \%)$ & $6,114(32 \%)$ & $181(1 \%)$ \\
\hline $18,935(100 \%)$ & $16,599(88 \%)$ & $2,336(12 \%)$
\end{tabular}




\begin{tabular}{|c|c|c|c|c|}
\hline \multicolumn{5}{|c|}{ Table 1 - continued } \\
\hline & Mean & Std. Dev. & Min & Max \\
\hline CEO Founder $(1=$ yes $0=$ no $)$ & $40.2 \%$ & $49.0 \%$ & $0.0 \%$ & $100.0 \%$ \\
\hline VC Minority Ownership (1=yes $0=$ no) & $77.1 \%$ & $42.0 \%$ & $0.0 \%$ & $100.0 \%$ \\
\hline & Mean & Std. Dev. & Min & Max \\
\hline Industry: Biopharmaceuticals & $10.3 \%$ & $30.4 \%$ & $0.0 \%$ & $100.0 \%$ \\
\hline Industry: Communications & $11.7 \%$ & $32.1 \%$ & $0.0 \%$ & $100.0 \%$ \\
\hline Industry: Cons/Bus Services & $13.0 \%$ & $33.7 \%$ & $0.0 \%$ & $100.0 \%$ \\
\hline Industry: Medical Devices & $10.1 \%$ & $30.1 \%$ & $0.0 \%$ & $100.0 \%$ \\
\hline Industry: Software & $28.9 \%$ & $45.3 \%$ & $0.0 \%$ & $100.0 \%$ \\
\hline Industry: Other & $26.0 \%$ & $43.9 \%$ & $0.0 \%$ & $100.0 \%$ \\
\hline Location: California & $42.5 \%$ & $49.4 \%$ & $0.0 \%$ & $100.0 \%$ \\
\hline Location: Massachussetts & $12.9 \%$ & $33.5 \%$ & $0.0 \%$ & $100.0 \%$ \\
\hline Location: Texas & $6.3 \%$ & $24.3 \%$ & $0.0 \%$ & $100.0 \%$ \\
\hline Location: Other & $38.3 \%$ & $48.6 \%$ & $0.0 \%$ & $100.0 \%$ \\
\hline \# Employees at End of Previous Year & 47 & 40 & 6 & 131 \\
\hline Revenues in Previous Year in $\$ 000$ s & $\$ 9,952$ & $\$ 18,931$ & $\$ 250$ & $\$ 65,000$ \\
\hline Profitable $(1=$ yes $0=$ no $)$ & $6.8 \%$ & $25.1 \%$ & $0.0 \%$ & $100.0 \%$ \\
\hline Company Age in Years) & 4.1 & 3.1 & 0.0 & 24.0 \\
\hline Company at Seed Stage & $1.3 \%$ & $11.4 \%$ & $0.0 \%$ & $100.0 \%$ \\
\hline \# of VC Rounds & 3.5 & 1.3 & 1.0 & 7.0 \\
\hline VC Financing in $\$ 000 \mathrm{~s}$ & $\$ 17,350$ & $\$ 27,368$ & $\$ 0$ & $\$ 320,280$ \\
\hline VC Experience (Number of Investments') & 133.3 & 173.1 & 0.0 & 500.0 \\
\hline VC Age (years) & 8.5 & 7.7 & 0.0 & 25.0 \\
\hline \multicolumn{5}{|c|}{ Panel F: Summary Statistics on Formal Compensation Policies (company-year observations) } \\
\hline & Mean & Std. Dev. & Min & $\operatorname{Max}$ \\
\hline Formal Compensation $(1=$ yes $0=$ no $)$ & $54.8 \%$ & $49.8 \%$ & $0.0 \%$ & $100.0 \%$ \\
\hline Formal Bonus $(1=$ yes $0=$ no $)$ & $44.1 \%$ & $49.7 \%$ & $0.0 \%$ & $100.0 \%$ \\
\hline Option Grant $(1=$ yes $0=$ no $)$ & $74.8 \%$ & $43.4 \%$ & $0.0 \%$ & $100.0 \%$ \\
\hline Sales Commission $(1=$ yes $0=$ no $)$ & $63.3 \%$ & $48.2 \%$ & $0.0 \%$ & $100.0 \%$ \\
\hline Hire-On Bonus $(1=$ yes $0=$ no) & $20.3 \%$ & $40.2 \%$ & $0.0 \%$ & $100.0 \%$ \\
\hline \# of Formal Compensation Policies & 2.6 & 1.3 & 0.0 & 5.0 \\
\hline \multicolumn{5}{|c|}{ Panel G: Summary Statistics on Employee Compensation (employee-year observations) } \\
\hline & Mean & Std. Dev. & Min & $\operatorname{Max}$ \\
\hline Cash Compensation in $\$ 000$ s & $\$ 161$ & $\$ 72$ & $\$ 5$ & $\$ 2,350$ \\
\hline Salary in $\$ 000$ s & $\$ 145$ & $\$ 57$ & $\$ 0$ & $\$ 1,950$ \\
\hline Bonus in $\$ 000 \mathrm{~s}$ & $\$ 14$ & $\$ 28$ & $\$ 0$ & $\$ 700$ \\
\hline Bonus $(1=$ yes $0=$ no $)$ & $37.9 \%$ & $48.5 \%$ & $0.0 \%$ & $100.0 \%$ \\
\hline Percentage Equity Ownership & $1.8 \%$ & $3.5 \%$ & $0.0 \%$ & $96.2 \%$ \\
\hline
\end{tabular}




\section{Table 2 - Formal Compensation Policies}

See Table 1 for description of sample. Each observation is a unique company-year. Regressions are ordered logit. Dependent variable is the Number of Formal Compensation Policies, defined as the sum of the five polices that are described in Table 1, Panel F. Specification 3 includes fixed effects for company location (U.S. state), company industry (VentureOne 16 groups), and survey year. Standard errors, clustered by company, are reported in square brackets. A constant is estimated but not reported. Two-tailed significance relative to zero is marked with * for $10 \%$, ** for $5 \%$ and $* * *$ for $1 \%$.

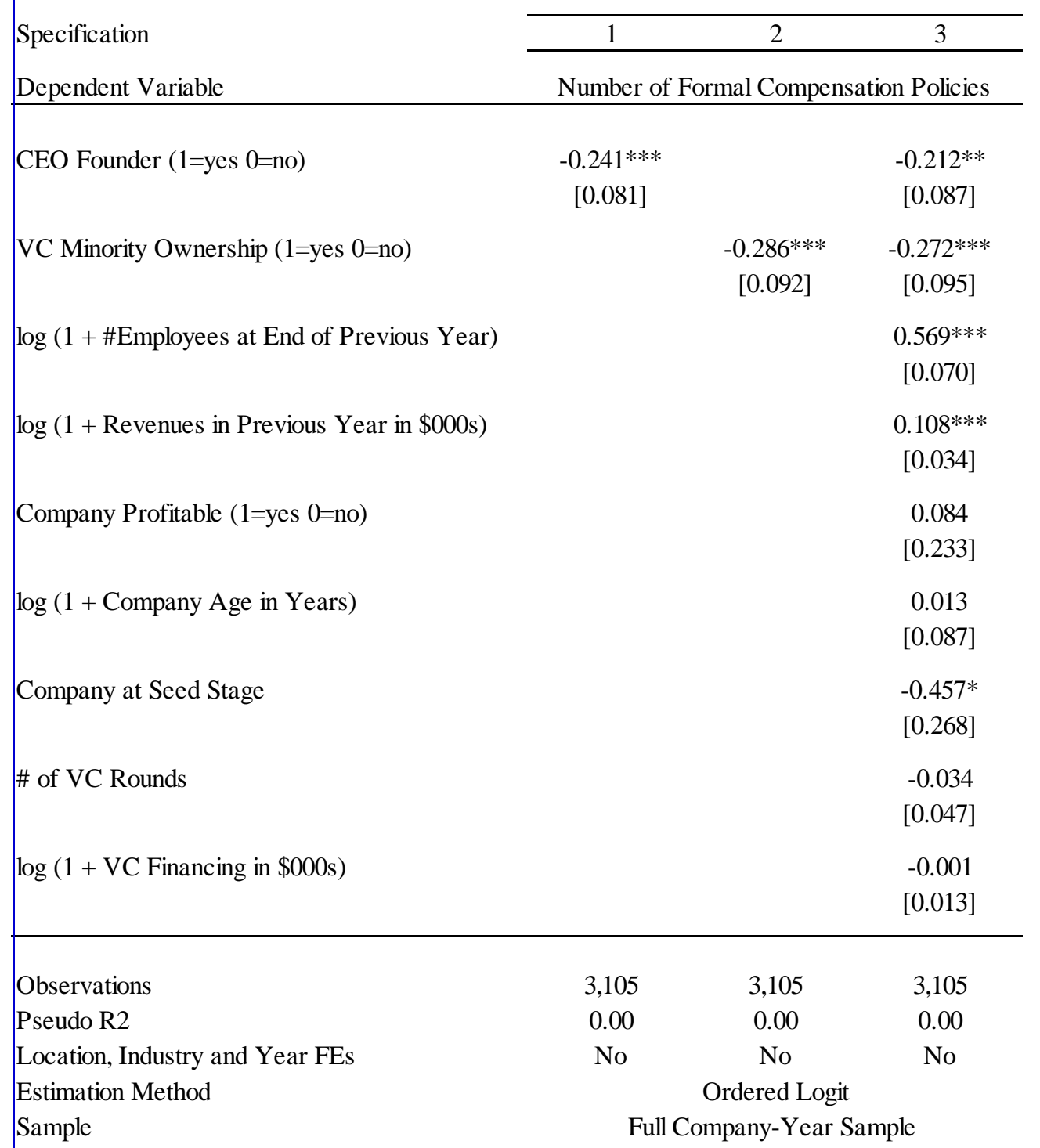




\section{Table 3 - Employee Cash Compensation}

See Table 1 for description of sample. Each observation is a unique employee-year. Regressions are OLS. Dependent variable is log $(1+$ Employee's Total Cash Compensation in \$000s), defined as the sum of Base Salary, Bonus, and Other Compensation. Specifications 3 and 4 include fixed effects for employee rank (Chief, Vice President or Director), company location (U.S. state), company industry (VentureOne 16 groups), and survey year. Standard errors, clustered by company, are reported in square brackets. A constant is estimated but not reported. Two-tailed test significance relative to zero is marked with $*$ for $10 \%, * *$ for $5 \%$ and $* * *$ for $1 \%$.

\begin{tabular}{|c|c|c|c|c|}
\hline \multirow{2}{*}{$\begin{array}{l}\text { Specification } \\
\text { Dependent Variable }\end{array}$} & \multirow[b]{2}{*}{$\log (1+$} & 2 & 3 & \multirow{2}{*}{$\begin{array}{r}4 \\
\$ 000 s)\end{array}$} \\
\hline & & ployee Cas & ompensation & \\
\hline CEO Founder $(1=$ yes $0=$ no $)$ & $\begin{array}{c}-0.053 * * * \\
{[0.018]}\end{array}$ & & $\begin{array}{c}-0.033 * * * \\
{[0.009]}\end{array}$ & $\begin{array}{c}-0.032 * * * \\
{[0.009]}\end{array}$ \\
\hline VC Minority Ownership ( $1=$ yes $0=$ no) & & $\begin{array}{c}-0.092^{* * * *} \\
{[0.012]}\end{array}$ & $\begin{array}{c}-0.049 * * * \\
{[0.011]}\end{array}$ & $\begin{array}{c}-0.044 * * * \\
{[0.011]}\end{array}$ \\
\hline Employee is Founder $(1=$ yes $0=$ no) & & & $\begin{array}{c}-0.050 * * * \\
{[0.010]}\end{array}$ & \\
\hline \# of Formal Compensation Policies & & & & $\begin{array}{c}0.028^{* * * *} \\
{[0.004]}\end{array}$ \\
\hline $\log (1+\#$ Employees at End of Previous Year $)$ & & & $\begin{array}{c}0.072 * * * \\
{[0.007]}\end{array}$ & $\begin{array}{c}0.065^{* * * *} \\
{[0.007]}\end{array}$ \\
\hline $\log (1+$ Revenues in Previous Year in $\$ 000$ s $)$ & & & $\begin{array}{l}0.007 * * \\
{[0.003]}\end{array}$ & $\begin{array}{c}0.005 \\
{[0.003]}\end{array}$ \\
\hline Company Profitable ( $1=$ yes $0=$ no) & & & $\begin{array}{c}0.001 \\
{[0.022]}\end{array}$ & $\begin{array}{l}-0.001 \\
{[0.021]}\end{array}$ \\
\hline $\log (1+$ Company Age in Years $)$ & & & $\begin{array}{c}-0.029 * * * \\
{[0.010]}\end{array}$ & $\begin{array}{c}-0.027 * * * \\
{[0.009]}\end{array}$ \\
\hline Company at Seed Stage & & & $\begin{array}{l}-0.063 \\
{[0.049]}\end{array}$ & $\begin{array}{l}-0.061 \\
{[0.048]}\end{array}$ \\
\hline \# of VC Rounds & & & $\begin{array}{l}-0.002 \\
{[0.005]}\end{array}$ & $\begin{array}{l}-0.002 \\
{[0.005]}\end{array}$ \\
\hline $\log (1+$ VC Financing in $\$ 000$ s $)$ & & & $\begin{array}{c}0.006^{* * *} \\
{[0.001]}\end{array}$ & $\begin{array}{c}0.006^{* * * *} \\
{[0.001]}\end{array}$ \\
\hline Observations & 18,935 & 18,935 & 18,935 & 18,935 \\
\hline R-squared & 0.01 & 0.01 & 0.37 & 0.37 \\
\hline Employee Rank Fixed Effects & No & No & Yes & Yes \\
\hline Location, Industry and Year Fixed Effects & No & No & Yes & Yes \\
\hline $\begin{array}{l}\text { Estimation Method } \\
\text { Sample }\end{array}$ & & Full Empl & Sample & \\
\hline
\end{tabular}




\section{Table 4 - Employee Cash and Equity Incentives}

See Table 1 for description of sample. Each observation is a unique employee-year. In specifications 1 2, regressions are probit, where estimated coefficients are adjusted to reflect variable means, and the dependent variable is Employee Receives a Cash Bonus (1=yes, 0=no). In specifications 3-4, regressions are tobit, and the dependent variable is Employee's Percentage Equity Ownership. Specifications 2 and 4 include fixed effects for employee rank (Chief, Vice President or Director), company location (U.S. state), company industry (VentureOne 16 groups), and survey year. Standard errors, clustered by company, are reported in square brackets. A constant is estimated but not reported. Two-tailed significance relative to zero is marked with * for $10 \%$, ** for $5 \%$ and *** for $1 \%$.

\begin{tabular}{|c|c|c|c|c|}
\hline \multirow{2}{*}{$\begin{array}{l}\text { Specification } \\
\text { Dependent Variable }\end{array}$} & 1 & 2 & 3 & 4 \\
\hline & \multicolumn{2}{|c|}{$\begin{array}{c}\text { Employee Receives Cash } \\
\text { Bonus }(1=\text { yes } 0=\text { no })\end{array}$} & \multicolumn{2}{|c|}{$\begin{array}{c}\text { Employee's Percentage Equity } \\
\text { Ownership }\end{array}$} \\
\hline CEO Founder $(1=$ yes $0=$ no $)$ & $\begin{array}{c}-0.042^{* *} \\
{[0.019]}\end{array}$ & $\begin{array}{l}-0.040 * \\
{[0.022]}\end{array}$ & $\begin{array}{c}0.000 \\
{[0.001]}\end{array}$ & $\begin{array}{c}-0.002^{* * *} \\
{[0.000]}\end{array}$ \\
\hline VC Minority Ownership (1=yes $0=$ no) & $\begin{array}{c}0.011 \\
{[0.023]}\end{array}$ & $\begin{array}{c}-0.054 * * \\
{[0.026]}\end{array}$ & $\begin{array}{c}0.004 * * * \\
{[0.001]}\end{array}$ & $\begin{array}{c}0.000 \\
{[0.001]}\end{array}$ \\
\hline Employee is Founder $(1=$ yes $0=$ no $)$ & & $\begin{array}{c}-0.051 * * * \\
{[0.017]}\end{array}$ & & $\begin{array}{c}0.032 * * * \\
{[0.001]}\end{array}$ \\
\hline $\log (1+$ \#Employees at End of Previous Year $)$ & & $\begin{array}{c}0.020 \\
{[0.019]}\end{array}$ & & $\begin{array}{c}-0.005^{* * *} \\
{[0.000]}\end{array}$ \\
\hline $\log (1+$ Revenues in Previous Year in $\$ 000 s)$ & & $\begin{array}{c}0.052 * * * \\
{[0.009]}\end{array}$ & & $\begin{array}{c}0.001 * * * \\
{[0.000]}\end{array}$ \\
\hline Company Profitable ( $1=$ yes $0=$ no) & & $\begin{array}{l}0.095^{* *} \\
{[0.048]}\end{array}$ & & $\begin{array}{c}0.000 \\
{[0.001]}\end{array}$ \\
\hline $\log (1+$ Company Age in Years $)$ & & $\begin{array}{c}0.014 \\
{[0.022]}\end{array}$ & & $\begin{array}{l}-0.001 * \\
{[0.000]}\end{array}$ \\
\hline Company at Seed Stage & & $\begin{array}{l}-0.003 \\
{[0.078]}\end{array}$ & & $\begin{array}{c}0.003 \\
{[0.002]}\end{array}$ \\
\hline \# of VC Rounds & & $\begin{array}{c}-0.027 * * \\
{[0.012]}\end{array}$ & & $\begin{array}{c}0.000 \\
{[0.000]}\end{array}$ \\
\hline $\log (1+$ VC Financing in $\$ 000 s)$ & & $\begin{array}{l}0.006^{*} \\
{[0.003]}\end{array}$ & & $\begin{array}{c}-0.000 * * * \\
{[0.000]}\end{array}$ \\
\hline $\begin{array}{l}\text { Observations } \\
\text { Pseudo R2 }\end{array}$ & $\begin{array}{c}18,935 \\
0.00\end{array}$ & $\begin{array}{c}18,935 \\
0.09\end{array}$ & 18,935 & 18,935 \\
\hline Employee Rank Fixed Effects & No & Yes & No & Yes \\
\hline Location, Industry and Year Fixed Effects & No & Yes & No & Yes \\
\hline Estimation Method & & & & \\
\hline Sample & Full Emp & Sample & Full Em & Sample \\
\hline
\end{tabular}




\section{Table 5 - Employee Compensation, Firm Fixed Effects}

See Table 1 for description of sample. Each observation is a unique employee-year. Regressions are OLS with firm fixed effects. Dependent variable varies with the specification. All specifications include fixed effects for employee rank (Chief, Vice President or Director) and survey year. Standard errors are reported in square brackets. A constant is estimated but not reported. Two-tailed test significance relative to zero is marked with * for $10 \%$, ** for $5 \%$ and $* * *$ for $1 \%$.

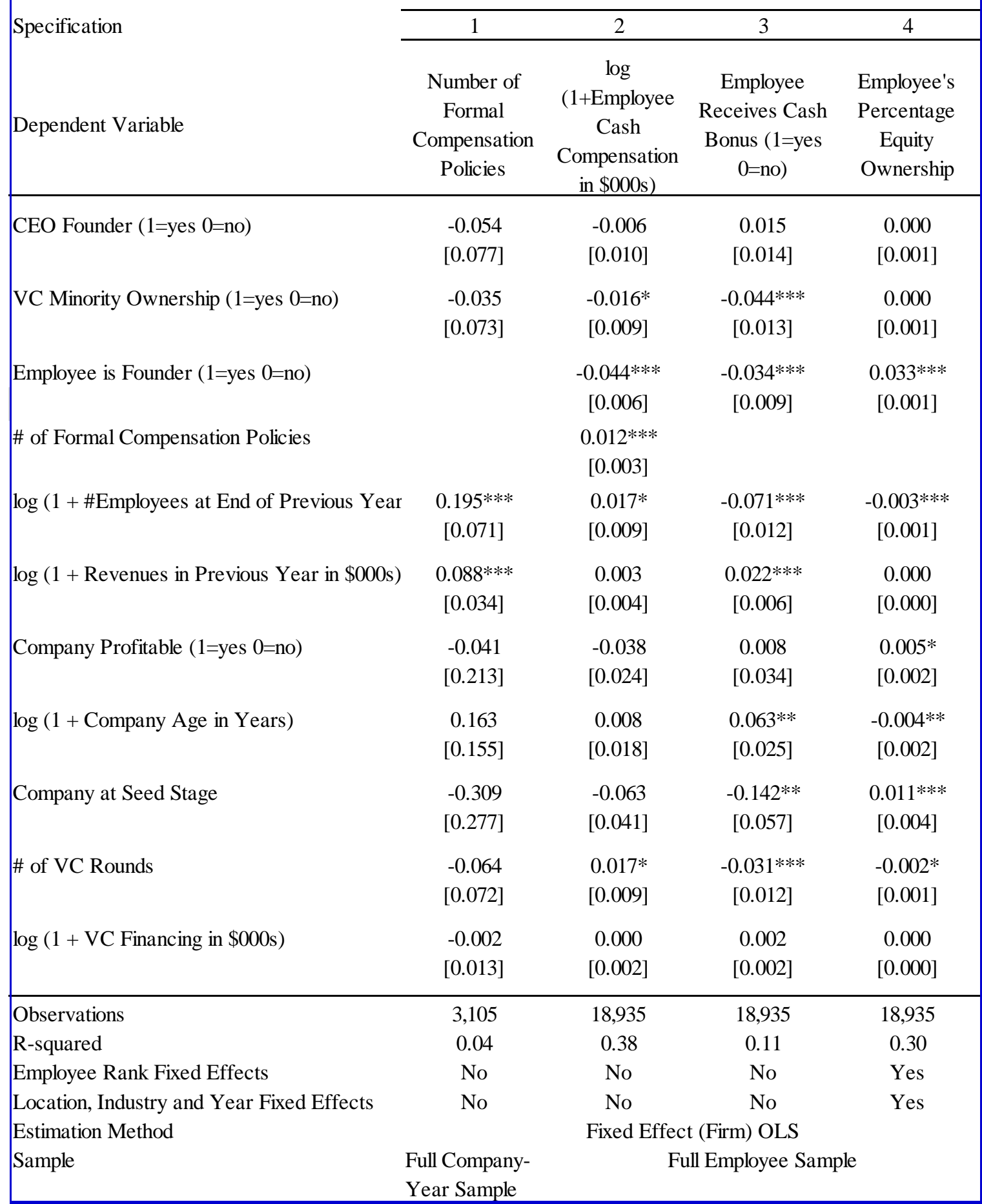




\section{Table 6 - Employee Compensation: Interaction Effects}

See Table 1 for description of sample. Each observation is a unique employee-year. Regressions are OLS. Dependent variable varies with the specification. fixed effects for employee rank (Chief, Vice President or Director), company location (U.S. state), company industry (VentureOne 16 groups), and survey year. Standard errors are reported in square brackets. A constant is estimated but not reported. Two-tailed test significance relative to zero is marked with * for $10 \%$, ** for $5 \%$ and $* * *$ for $1 \%$.

\begin{tabular}{|c|c|c|c|}
\hline \multirow[b]{2}{*}{ Specification } & \multirow{2}{*}{\multicolumn{2}{|c|}{1}} & \multirow[b]{2}{*}{3} \\
\hline & & & \\
\hline Dependent Variable & $\begin{array}{c}\log (1+\text { Employee } \\
\text { Cash Compensation } \\
\text { in } \$ 000 \mathrm{~s})\end{array}$ & $\begin{array}{c}\text { Employee Receives } \\
\text { Cash Bonus (1=yes } \\
0=\text { no) }\end{array}$ & $\begin{array}{c}\text { Employee's } \\
\text { Percentage Equity } \\
\text { Ownership }\end{array}$ \\
\hline CEO Founder $(1=$ yes $0=$ no $) X$ & $0.051 * * *$ & 0.018 & -0.001 \\
\hline Employee is Founder ( $1=$ yes $0=$ no) & [0.019] & [0.033] & [0.001] \\
\hline $\begin{array}{c}\text { VC Minority Ownership }(1=\text { yes } 0=\text { no }) X \\
\text { Employee is Founder }(1=\text { yes } 0=\text { no })\end{array}$ & $\begin{array}{c}0.032 \\
{[0.025]}\end{array}$ & $\begin{array}{c}-0.006 \\
{[0.039]}\end{array}$ & $\begin{array}{c}0.021 * * * \\
{[0.002]}\end{array}$ \\
\hline CEO Founder $(1=$ yes $0=$ no $)$ & $\begin{array}{c}-0.039 * * * \\
{[0.010]}\end{array}$ & $\begin{array}{l}-0.042^{*} \\
{[0.023]}\end{array}$ & $\begin{array}{c}-0.002 * * * \\
{[0.001]}\end{array}$ \\
\hline VC Minority Ownership (1=yes 0=no) & $\begin{array}{c}-0.053^{* * *} \\
{[0.012]}\end{array}$ & $\begin{array}{l}-0.053^{*} \\
{[0.027]}\end{array}$ & $\begin{array}{c}-0.003 * * * \\
{[0.001]}\end{array}$ \\
\hline Employee is Founder ( $1=$ yes $0=$ no) & $\begin{array}{c}-0.082^{* * * *} \\
{[0.012]}\end{array}$ & $\begin{array}{c}-0.057 * * \\
{[0.023]}\end{array}$ & $\begin{array}{c}0.028 * * * \\
{[0.001]}\end{array}$ \\
\hline $\log (1+\#$ Employees at End of Previous Year & $\begin{array}{c}0.072 * * * \\
{[0.007]}\end{array}$ & $\begin{array}{c}0.020 \\
{[0.019]}\end{array}$ & $\begin{array}{c}-0.005^{* * *} \\
{[0.000]}\end{array}$ \\
\hline $\log (1+$ Revenues in Previous Year in $\$ 000$ s $)$ & $\begin{array}{l}0.007 * * \\
{[0.003]}\end{array}$ & $\begin{array}{c}0.052 * * * \\
{[0.009]}\end{array}$ & $\begin{array}{c}0.001^{* * *} \\
{[0.000]}\end{array}$ \\
\hline Company Profitable ( $1=$ yes $0=$ no) & $\begin{array}{c}0.000 \\
{[0.022]}\end{array}$ & $\begin{array}{l}0.095^{*} \\
{[0.048]}\end{array}$ & $\begin{array}{c}0.000 \\
{[0.001]}\end{array}$ \\
\hline $\log (1+$ Company Age in Years $)$ & $\begin{array}{c}-0.028 * * * \\
{[0.010]}\end{array}$ & $\begin{array}{c}0.014 \\
{[0.022]}\end{array}$ & $\begin{array}{c}-0.001 \\
{[0.000]}\end{array}$ \\
\hline Company at Seed Stage & $\begin{array}{r}-0.066 \\
{[0.049]}\end{array}$ & $\begin{array}{c}-0.002 \\
{[0.078]}\end{array}$ & $\begin{array}{c}0.002 \\
{[0.002]}\end{array}$ \\
\hline \# of VC Rounds & $\begin{array}{c}-0.002 \\
{[0.005]}\end{array}$ & $\begin{array}{c}-0.027 * * \\
{[0.012]}\end{array}$ & $\begin{array}{l}-0.000^{*} \\
{[0.000]}\end{array}$ \\
\hline $\log (1+$ VC Financing in $\$ 000 s)$ & $\begin{array}{c}0.006^{* * *} \\
{[0.001]}\end{array}$ & $\begin{array}{l}0.006^{*} \\
{[0.003]}\end{array}$ & $\begin{array}{c}-0.000^{* * * *} \\
{[0.000]}\end{array}$ \\
\hline Observations & 3,105 & 18,935 & 18,935 \\
\hline R-squared & 0.37 & 0.09 & \\
\hline Employee Rank Fixed Effects & No & No & No \\
\hline Location, Industry and Year Fixed Effects & No & No & No \\
\hline Estimation Method & OLS & Probit & Tobit \\
\hline Sample & & Full Employee Sample & \\
\hline
\end{tabular}




\section{Table 7 - Company Maturity and Operating Performance}

See Table 1 for description of sample. Each observation is a unique company-year. Specifications 1-6 are OLS regressions. Specifications 7-8 are probit regressions, where estimated coefficients are adjusted to reflect variable means. Dependent variable are different proxies for company maturity and operating performance. Even-numbered specifications include fixed effects for company location (U.S. state), company industry (VentureOne 16 groups), survey year, and round number. Standard errors, clustered by company, are reported in square brackets. A constant is estimated but not reported. Two-tailed significance relative to zero is marked with * for $10 \%$, ** for $5 \%$ and *** for $1 \%$.

\begin{tabular}{|c|c|c|c|c|c|c|c|c|}
\hline \multirow{2}{*}{$\begin{array}{l}\text { Specification } \\
\text { Dependent Variable }\end{array}$} & \multicolumn{2}{|c|}{$12 \quad 2$} & 3 & 4 & 5 & 6 & 7 & 8 \\
\hline & $\begin{array}{c}\log (1+ \\
\text { Age in }\end{array}$ & $\begin{array}{l}\text { Company } \\
\text { Years) }\end{array}$ & $\begin{array}{r}\log (1+\# 1 \\
\text { at End of } \\
\mathrm{Ye}\end{array}$ & $\begin{array}{l}\text { mployees } \\
\text { Previous } \\
\text { r) }\end{array}$ & $\begin{array}{r}\log (1+\mathrm{F} \\
\text { Previou } \\
\$ 0\end{array}$ & $\begin{array}{l}\text { evenues in } \\
\text { Year in } \\
0 \text { s) }\end{array}$ & $\begin{array}{r}\text { Company } \\
(1=y e\end{array}$ & $\begin{array}{l}\text { Profitable } \\
0=\text { no) }\end{array}$ \\
\hline CEO Founder $(1=$ yes $0=$ no $)$ & $\begin{array}{l}-0.065^{*} \\
{[0.035]}\end{array}$ & $\begin{array}{c}0.133 * * * \\
{[0.032]}\end{array}$ & $\begin{array}{c}-0.166^{* * *} \\
{[0.046]}\end{array}$ & $\begin{array}{c}0.002 \\
{[0.041]}\end{array}$ & $\begin{array}{l}0.225^{* *} \\
{[0.093]}\end{array}$ & $\begin{array}{c}0.387 * * * \\
{[0.084]}\end{array}$ & $\begin{array}{c}0.059 * * * \\
{[0.016]}\end{array}$ & $\begin{array}{c}0.040^{* * * *} \\
{[0.011]}\end{array}$ \\
\hline VC Minority Ownership ( $1=$ yes $0=$ no) & $\begin{array}{c}-0.257 * * * \\
{[0.029]}\end{array}$ & $\begin{array}{c}-0.149 * * * \\
{[0.025]}\end{array}$ & $\begin{array}{c}-0.052 \\
{[0.041]}\end{array}$ & $\begin{array}{c}0.046 \\
{[0.035]}\end{array}$ & $\begin{array}{l}-0.107 \\
{[0.085]}\end{array}$ & $\begin{array}{c}0.030 \\
{[0.071]}\end{array}$ & $\begin{array}{c}0.017 \\
{[0.011]}\end{array}$ & $\begin{array}{l}0.012^{*} \\
{[0.007]}\end{array}$ \\
\hline Observations & 3,105 & 3,105 & 3,105 & 3,105 & 3,105 & 3,105 & 3,105 & 3,105 \\
\hline Pseudo R2 & 0.04 & 0.39 & 0.01 & 0.29 & 0.00 & 0.35 & 0.02 & 0.21 \\
\hline Location, Industry and Year FEs & No & Yes & No & Yes & No & Yes & No & Yes \\
\hline Round FEs & No & Yes & No & Yes & No & Yes & No & Yes \\
\hline $\begin{array}{l}\text { Estimation Method } \\
\text { Sample }\end{array}$ & & & $\begin{array}{r}\mathrm{O} \\
\mathrm{Fu}\end{array}$ & $\begin{array}{l}\text { S } \\
\text { Company }\end{array}$ & Year Sam & & & obit \\
\hline
\end{tabular}


Table 8 - Employee Human Capital

Sample is all individuals listed in CapitalIQ as non-CEO "Chiefs" (e.g., CFO, COO, CIO) as of October 2011. Each observation is a unique employee. Dependent variable varies with the specification. All specifications include fixed effects for company location (U.S. state), company industry (CapitallQ 140 groups), employee title and survey year. Standard errors are clustered by company, and reported in square brackets. A constant is estimated but not reported. Two-tailed test significance relative to zero is marked with * for $10 \%$, ** for $5 \%$

Specification

\begin{tabular}{|c|c|c|c|c|c|c|}
\hline Specification & 1 & 2 & 3 & 4 & 5 & 6 \\
\hline Dependent Variable & $\begin{array}{l}\log (1+\text { Age of } \\
\text { Executive })\end{array}$ & $\begin{array}{l}\text { Employee Has } \\
\text { Any Affiliation } \\
(1=\text { yes, } 0=\text { no })\end{array}$ & $\begin{array}{c}\log (1+\text { Number } \\
\text { of Employee's } \\
\text { Affiliations }\end{array}$ & $\begin{array}{l}\text { Employee Holds } \\
\text { a PhD degree } \\
(1=\text { yes, } 0=\text { no })\end{array}$ & $\begin{array}{c}\text { Employee Holds } \\
\text { a MBA degree } \\
(1=\text { yes, } 0=\text { no })\end{array}$ & $\begin{array}{c}\text { Employee } \\
\text { Attended Top } \\
\text { University } \\
(1=\text { yes, } 0=\text { no })\end{array}$ \\
\hline CEO Founder $(1=$ yes $0=$ no $)$ & $\begin{array}{c}-0.018 * * \\
{[0.008]}\end{array}$ & $\begin{array}{c}-0.144 * * * \\
{[0.044]}\end{array}$ & $\begin{array}{c}-0.043^{* * *} \\
{[0.011]}\end{array}$ & $\begin{array}{c}-0.174 * * \\
{[0.085]}\end{array}$ & $\begin{array}{c}0.047 \\
{[0.056]}\end{array}$ & $\begin{array}{c}0.060 \\
{[0.047]}\end{array}$ \\
\hline Employee is Founder $(1=$ yes $0=$ no $)$ & $\begin{array}{c}-0.009 \\
{[0.016]}\end{array}$ & $\begin{array}{c}-0.443 * * * \\
{[0.057]}\end{array}$ & $\begin{array}{c}-0.104 * * * \\
{[0.013]}\end{array}$ & $\begin{array}{c}0.103 \\
{[0.090]}\end{array}$ & $\begin{array}{c}-0.072 \\
{[0.086]}\end{array}$ & $\begin{array}{c}0.274 * * * \\
{[0.059]}\end{array}$ \\
\hline $\log (1+$ \#Employees at End of Previous Year & $\begin{array}{l}-0.005 \\
{[0.005]}\end{array}$ & $\begin{array}{c}0.136 * * * \\
{[0.038]}\end{array}$ & $\begin{array}{l}0.027 * * \\
{[0.011]}\end{array}$ & $\begin{array}{l}-0.006 \\
{[0.074]}\end{array}$ & $\begin{array}{c}0.022 \\
{[0.045]}\end{array}$ & $\begin{array}{c}0.082 * * \\
{[0.042]}\end{array}$ \\
\hline $\log (1+$ Company Age in Years $)$ & $\begin{array}{c}0.026 * * * \\
{[0.008]}\end{array}$ & $\begin{array}{c}-0.320 * * * \\
{[0.048]}\end{array}$ & $\begin{array}{c}-0.090 * * * \\
{[0.013]}\end{array}$ & $\begin{array}{l}-0.015 \\
{[0.091]}\end{array}$ & $\begin{array}{l}-0.036 \\
{[0.064]}\end{array}$ & $\begin{array}{l}-0.027 \\
{[0.053]}\end{array}$ \\
\hline Observations & 2,394 & 14,329 & 14,329 & 14,329 & 14,329 & 14,329 \\
\hline R-squared & 0.14 & 0.06 & 0.11 & 0.25 & 0.11 & 0.07 \\
\hline Employee Rank Fixed Effects & Yes & Yes & Yes & Yes & Yes & Yes \\
\hline Location, Industry and Year Fixed Effects & Yes & Yes & Yes & Yes & Yes & Yes \\
\hline Estimation Method & OLS & Probit & OLS & Probit & Probit & Probit \\
\hline Sample & \multicolumn{6}{|c|}{ New Employee Biography Sample } \\
\hline
\end{tabular}




\section{Appendix Table A - VC Fundraising}

See Table 1 for description of sample. Each observation is a unique company-year. Specification 1 is ordered logit regression, and specifications 2-4 are OLS regressions. Dependent variables are VC $\%$ Ownership in specification 1, log $(1+$ total amount of VC financing raised in all rounds) in specification 2, Number of VC Rounds in specification 3, and log (1+VC financing) / Number of VC Rounds in specification 4. All specifications includes fixed effects for company location (U.S. state), company industry (VentureOne 16 groups), and survey year. Standard errors, clustered by company, are reported in square brackets. A constant is estimated but not reported. Two-tailed significance relative to zero is marked with * for $10 \%$, ** for $5 \%$ and $* * *$ for $1 \%$.

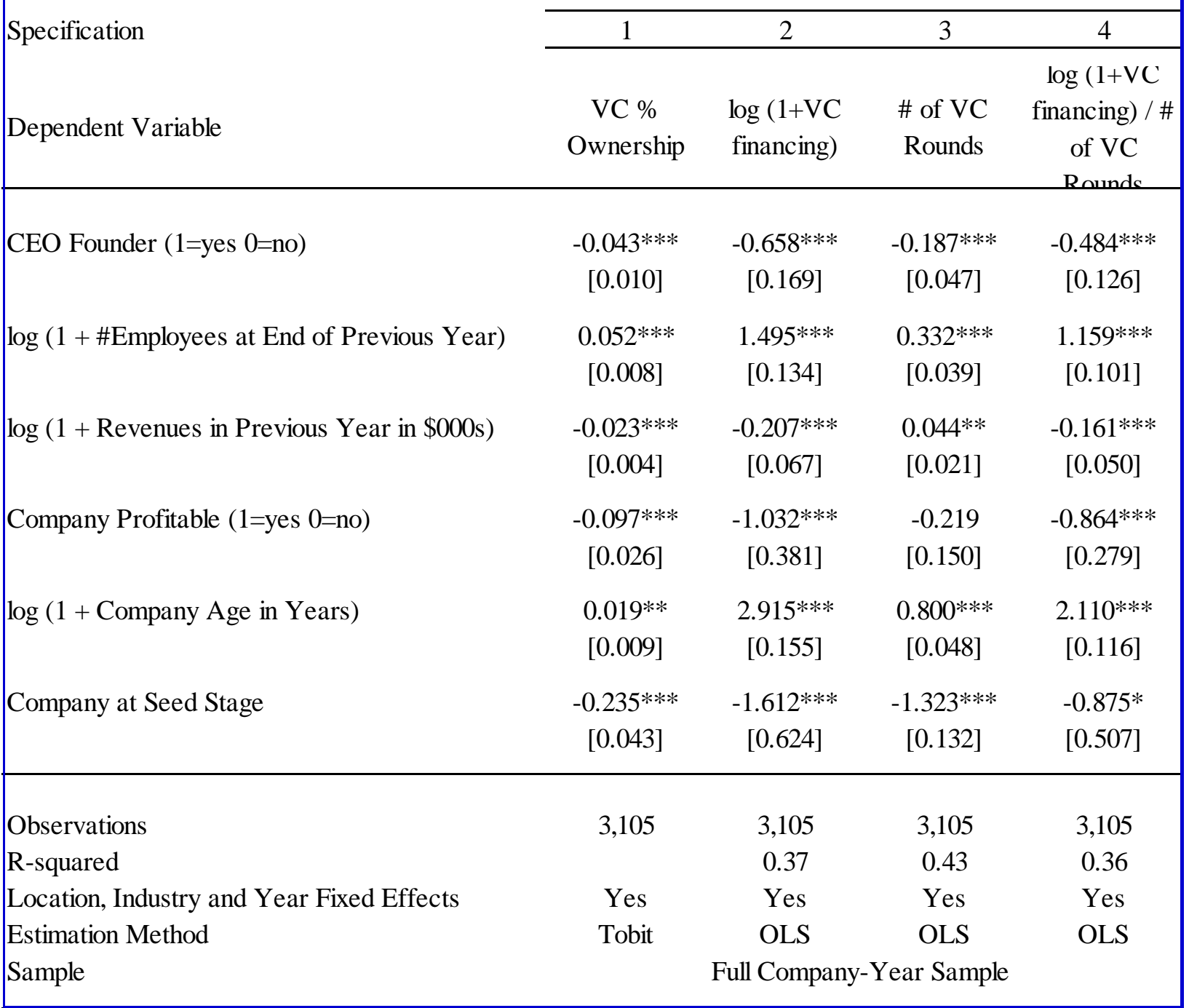




\begin{tabular}{|c|c|c|c|c|c|}
\hline $\begin{array}{l}\text { Appendix Table B - Individ } \\
\text { See Table } 1 \text { for description of sample. Ec } \\
\text { probit, where estimated coefficients are adj } \\
\text { Formal Compensation Policy. All specifica } \\
\text { company industry (VentureOne } 16 \text { groups } \\
\text { are reported in square brackets. A cons } \\
\text { relative to zero is marked with } * \text { for } 10 \% \text {, * }\end{array}$ & $\begin{array}{l}\text { Ual Formal C } \\
\text { ach observati } \\
\text { justed to refle } \\
\text { tions include } \\
\text {, and survey } \\
\text { stant is estim } \\
* * \text { for } 5 \% \text { and }\end{array}$ & $\begin{array}{l}\text { mpensatic } \\
\text { on is a uni } \\
\text { ct variable } \\
\text { fixed effec } \\
\text { year. Sta } \\
\text { ted but nc } \\
* * * \text { for } 1 \text {. }\end{array}$ & $\begin{array}{l}\text { Policies } \\
\text { ue compan. } \\
\text { leans. Each } \\
\text { for compa } \\
\text { lard errors } \\
\text { reported. }\end{array}$ & $\begin{array}{l}\text { y-year. Regr } \\
\text { dependent } v \\
\text { ny location } \\
\text { clustered b } \\
\text { Two-tailed }\end{array}$ & $\begin{array}{l}\text { ssions are } \\
\text { iriable is a } \\
\text { U.S. state), } \\
\text { company, } \\
\text { ignificance }\end{array}$ \\
\hline Specification & 1 & 2 & 3 & 4 & 5 \\
\hline Dependent Variable & $\begin{array}{c}\text { Formal } \\
\text { Compensatio } \\
\text { n }(1=\text { yes } \\
0=\text { no })\end{array}$ & $\begin{array}{l}\text { Formal } \\
\text { Bonus } \\
(1=\text { yes } \\
0=\text { no) }\end{array}$ & $\begin{array}{c}\text { Option } \\
\text { Grant } \\
(1=\text { yes } \\
0=\text { no) }\end{array}$ & $\begin{array}{c}\text { Sales } \\
\text { Commission } \\
\begin{array}{c}(1=\mathrm{yes} \\
0=\mathrm{no})\end{array}\end{array}$ & $\begin{array}{c}\text { Hire-On } \\
\text { Bonus } \\
(1=\text { yes } \\
0=\text { no })\end{array}$ \\
\hline CEO Founder $(1=$ yes $0=$ no $)$ & $\begin{array}{c}-0.028 \\
{[0.023]}\end{array}$ & $\begin{array}{c}-0.002 \\
{[0.020]}\end{array}$ & $\begin{array}{c}-0.070 * * * \\
{[0.026]}\end{array}$ & $\begin{array}{c}-0.017 \\
{[0.017]}\end{array}$ & $\begin{array}{l}-0.044 * \\
0.024]\end{array}$ \\
\hline VC Minority Ownership (1=yes $0=$ no) & $\begin{array}{c}-0.028 \\
{[0.026]}\end{array}$ & $\begin{array}{c}-0.051 * * \\
{[0.023]}\end{array}$ & $\begin{array}{c}-0.079 * * * \\
{[0.029]}\end{array}$ & $\begin{array}{c}-0.007 \\
{[0.020]}\end{array}$ & $\begin{array}{c}-0.057 * * \\
{[0.026]}\end{array}$ \\
\hline $\log (1+$ \#Employees at End of Previous Year & $\begin{array}{c}0.118^{* * * *} \\
{[0.019]}\end{array}$ & $\begin{array}{c}0.087 * * * \\
{[0.016]}\end{array}$ & $\begin{array}{c}0.096^{* * * *} \\
{[0.021]}\end{array}$ & $\begin{array}{c}0.047 * * * \\
{[0.014]}\end{array}$ & $\begin{array}{c}0.069 * * * \\
{[0.019]}\end{array}$ \\
\hline $\log (1+$ Revenues in Previous Year in $\$ 000$ s $)$ & $\begin{array}{c}-0.021 * * \\
{[0.010]}\end{array}$ & $\begin{array}{l}-0.015^{*} \\
{[0.008]}\end{array}$ & $\begin{array}{c}0.100 * * * \\
{[0.011]}\end{array}$ & $\begin{array}{c}-0.008 \\
{[0.007]}\end{array}$ & $\begin{array}{c}0.043^{* * *} \\
{[0.010]}\end{array}$ \\
\hline Company Profitable $(1=$ yes $0=$ no $)$ & $\begin{array}{c}0.017 \\
{[0.051]}\end{array}$ & $\begin{array}{l}-0.081 * \\
{[0.046]}\end{array}$ & $\begin{array}{c}-0.137 * * \\
{[0.068]}\end{array}$ & $\begin{array}{c}0.089^{*} \\
{[0.046]}\end{array}$ & $\begin{array}{c}0.097^{*} \\
{[0.050]}\end{array}$ \\
\hline $\log (1+$ Company Age in Years $)$ & $\begin{array}{c}-0.008 \\
{[0.023]}\end{array}$ & $\begin{array}{c}-0.028 \\
{[0.019]}\end{array}$ & $\begin{array}{c}0.028 \\
{[0.026]}\end{array}$ & $\begin{array}{c}0.005 \\
{[0.017]}\end{array}$ & $\begin{array}{c}0.032 \\
{[0.024]}\end{array}$ \\
\hline Company at Seed Stage & $\begin{array}{c}-0.078 \\
{[0.076]}\end{array}$ & $\begin{array}{c}-0.018 \\
{[0.061]}\end{array}$ & $\begin{array}{c}-0.091 \\
{[0.082]}\end{array}$ & $\begin{array}{c}0.025 \\
{[0.059]}\end{array}$ & $\begin{array}{c}-0.163^{* *} \\
{[0.068]}\end{array}$ \\
\hline \# of VC Rounds & $\begin{array}{c}-0.013 \\
{[0.013]}\end{array}$ & $\begin{array}{c}0.010 \\
{[0.011]}\end{array}$ & $\begin{array}{c}0.021 \\
{[0.016]}\end{array}$ & $\begin{array}{c}0.000 \\
{[0.010]}\end{array}$ & $\begin{array}{c}-0.029 * * \\
{[0.014]}\end{array}$ \\
\hline $\log (1+$ VC Financing in $\$ 000 s)$ & $\begin{array}{c}-0.001 \\
{[0.003]}\end{array}$ & $\begin{array}{c}-0.001 \\
{[0.003]}\end{array}$ & $\begin{array}{c}-0.006 \\
{[0.004]}\end{array}$ & $\begin{array}{c}0.003 \\
{[0.003]}\end{array}$ & $\begin{array}{c}0.002 \\
{[0.004]}\end{array}$ \\
\hline $\begin{array}{l}\text { Observations } \\
\text { Pseudo R2 } \\
\text { Location, Industry and Year FEs } \\
\text { Estimation Method } \\
\text { Sample }\end{array}$ & $\begin{array}{c}3,105 \\
0.00 \\
\text { No }\end{array}$ & $\begin{array}{l}3,105 \\
0.00 \\
\text { No } \\
\text { Full Co }\end{array}$ & $\begin{array}{c}3,105 \\
0.00 \\
\text { No } \\
\text { Probit } \\
\text { pany-Year }\end{array}$ & $\begin{array}{r}\begin{array}{r}3,105 \\
0.07 \\
\text { Yes }\end{array} \\
\text { Sample }\end{array}$ & $\begin{array}{l}3,105 \\
0.07 \\
\text { Yes }\end{array}$ \\
\hline
\end{tabular}




\section{Appendix Table C - Employee Cash Compensation, Robustness}

See Table 1 for description of sample. Each observation is a unique employee-year. Regressions are OLS. Dependent variable is log $(1+$ Employee's Total Cash Compensation in \$000s), defined as the sum of Base Salary, Bonus, and Other Compensation. All specifications control for Round Number, \#Employees at End of Previous Year, Revenues in Previous Year in \$000s, Profitable (1=yes 0=no), Company Age in Years), Company at Seed Stage, and VC Financing in \$000s, and include fixed effects for employee rank (Chief, Vice President or Director), company location (U.S. state), company industry (VentureOne 16 groups), and survey year. Standard errors, clustered by company, are reported in square brackets. A constant is estimated but not reported. Two-tailed significance relative to zero is marked with * for $10 \%$, ** for $5 \%$ and $* * *$ for $1 \%$.

Explanatory Variable:

Employee Rank: Chief

Employee Rank: Vice President

Employee Rank: Director

Location: California

Location: Massachussetts

Location: Texas

Location: Other

Industry: Communications

Industry: Biopharmaceuticals

Industry: Cons/Bus Services

Industry: Medical Devices

Industry: Software

Industry: Other

Survey Year: 2002-2003

Survey Year: 2004-2005

Survey Year: 2006-2007

Employees: Below Sample Median

Employees: Above or at Sample Median

Revenues: Below Sample Median

Revenues: Above or at Sample Median

Company Age: Below Sample Median

Company Age: Above or at Sample Median

VC Financing: Below Sample Median

VC Financing: Above Sample Median

\begin{tabular}{|c|c|c|c|c|c|c|}
\hline CEO Founder & VC Minority & y Ownership & Employee & is Founder & \# Obs. & R-squared \\
\hline$-0.026^{* * *}[0.009]$ & $-0.025 * *$ & [0.011] & $-0.046^{*}$ & {$[0.028]$} & 4,349 & 0.25 \\
\hline$-0.037 * * *[0.010]$ & $-0.056^{* * *}$ & {$[0.013]$} & $-0.045^{* * *}$ & [0.012] & 8,291 & 0.19 \\
\hline$-0.035^{*}[0.020]$ & $-0.049 * * *$ & {$[0.014]$} & 0.034 & {$[0.031]$} & 6,295 & 0.15 \\
\hline$-0.030 * *[0.014]$ & $-0.063 * * *$ & [0.017] & $-0.048 * * *$ & {$[0.017]$} & 8,044 & 0.38 \\
\hline $0.005[0.012]$ & 0.011 & {$[0.025]$} & $-0.058 * *$ & {$[0.029]$} & 2,442 & 0.41 \\
\hline$-0.019[0.025]$ & -0.007 & [0.049] & $-0.059 *$ & {$[0.033]$} & 1,188 & 0.30 \\
\hline$-0.051 * * *[0.016]$ & $-0.057 *$ & {$[0.029]$} & $-0.045 * * *$ & {$[0.013]$} & 7,261 & 0.37 \\
\hline$-0.005[0.014]$ & $-0.064 *$ & {$[0.033]$} & -0.042 & {$[0.026]$} & 2,212 & 0.36 \\
\hline$-0.013[0.028]$ & $-0.117 * * *$ & [0.043] & 0.021 & {$[0.028]$} & 1,954 & 0.43 \\
\hline$-0.009[0.021]$ & -0.025 & {$[0.022]$} & $-0.058^{*}$ & {$[0.031]$} & 2,469 & 0.47 \\
\hline$-0.066 * * *[0.014]$ & 0.001 & [0.026] & -0.032 & [0.026] & 1,904 & 0.44 \\
\hline$-0.032 *[0.019]$ & $-0.057 * * *$ & {$[0.017]$} & $-0.066^{* * *}$ & {$[0.025]$} & 5,465 & 0.36 \\
\hline$-0.046^{* * * *}[0.009]$ & $-0.028 * * *$ & [0.011] & $-0.042 * * *$ & {$[0.012]$} & 4,931 & 0.41 \\
\hline$-0.016 * * *[0.005]$ & $-0.047 * * *$ & {$[0.010]$} & $-0.050 * * *$ & {$[0.010]$} & 4,640 & 0.38 \\
\hline$-0.053 * * *[0.019]$ & $-0.069 * * *$ & {$[0.009]$} & $-0.066 * *$ & {$[0.027]$} & 8,182 & 0.35 \\
\hline$-0.021[0.019]$ & -0.028 & [0.032] & -0.034 & {$[0.022]$} & 6,113 & 0.43 \\
\hline$-0.046 * * *[0.015]$ & $-0.065^{* * *}$ & [0.011] & $-0.060 * * *$ & [0.016] & 9,461 & 0.32 \\
\hline$-0.026^{* *}[0.012]$ & -0.025 & [0.019] & $-0.027^{*}$ & {$[0.014]$} & 9,474 & 0.42 \\
\hline$-0.043 * * *[0.014]$ & $-0.086^{* * *}$ & [0.019] & $-0.059 * * *$ & {$[0.013]$} & 7,734 & 0.34 \\
\hline$-0.030 * * *[0.012]$ & -0.026 & {$[0.018]$} & $-0.038 * *$ & {$[0.018]$} & 11,201 & 0.41 \\
\hline$-0.021 * * *[0.007]$ & $-0.071 * * *$ & {$[0.008]$} & $-0.058 * * *$ & {$[0.011]$} & 9,168 & 0.38 \\
\hline$-0.047 * * *[0.017]$ & -0.022 & {$[0.015]$} & -0.039 & {$[0.028]$} & 9,767 & 0.38 \\
\hline$-0.033 * * *[0.012]$ & $-0.068 * * *$ & [0.008] & $-0.052 * * *$ & [0.016] & 9,476 & 0.35 \\
\hline$-0.038 *[0.023]$ & -0.019 & [0.023] & $-0.040 * * *$ & [0.012] & 9,459 & 0.40 \\
\hline
\end{tabular}

